4

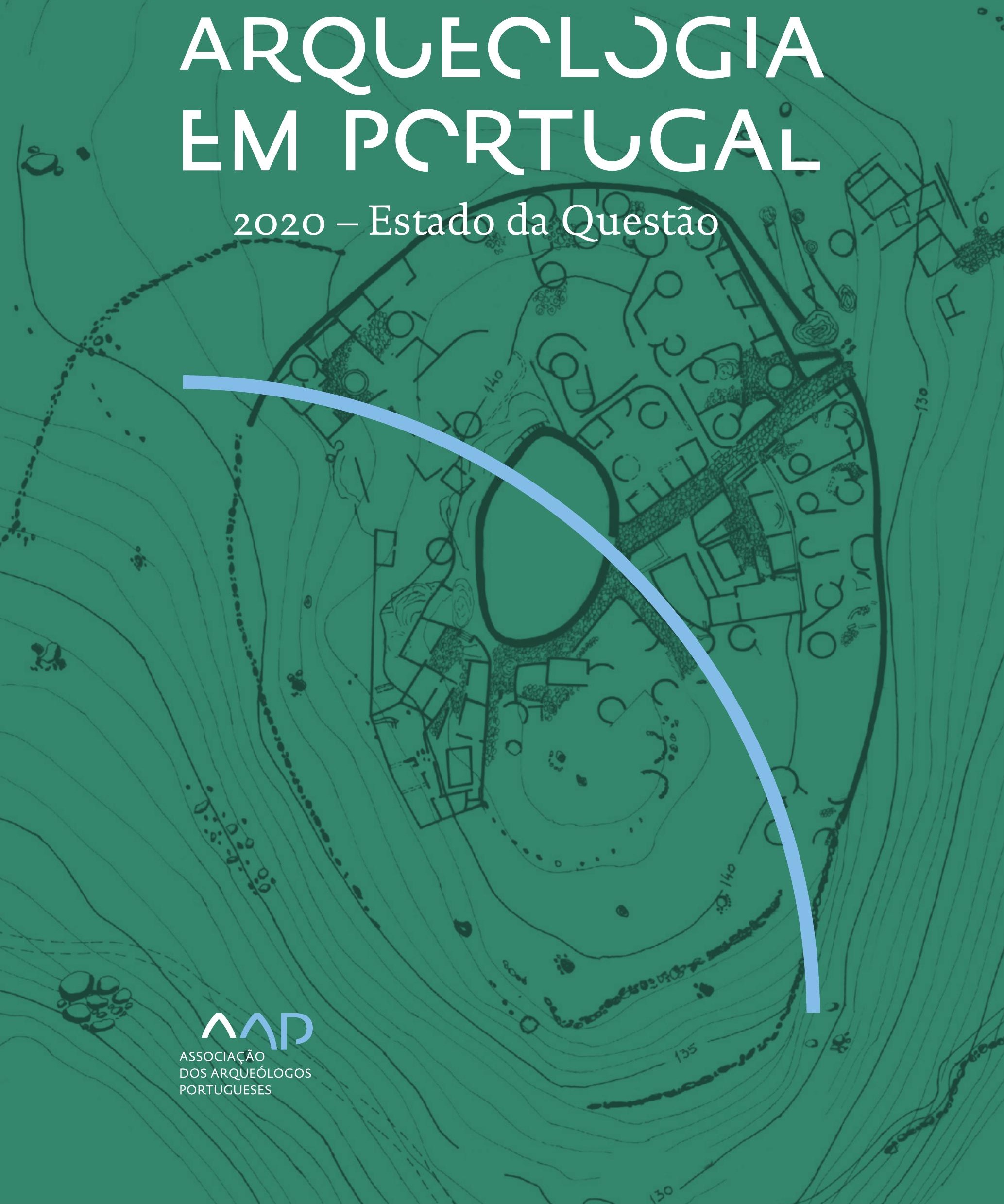


Coordenação editorial: José Morais Arnaud, César Neves e Andrea Martins Design gráfico: Flatland Design

AAP - ISBN: 978-972-9451-89-8

CITCEM - ISBN: 978-989-8970-25-1

Associação dos Arqueólogos Portugueses e CITCEM

Lisboa, 2020

O conteúdo dos artigos é da inteira responsabilidade dos autores. Sendo assim a Associação dos Arqueólogos Portugueses declina qualquer responsabilidade por eventuais equívocos ou questões de ordem ética e legal.

Desenho de capa:

Planta do castro de Monte Mozinho (Museu Municipal de Penafiel).

\section{$\hat{\wedge} \mathrm{P}$}

DOS ARQUEÓLOGOS PORTUGUESES

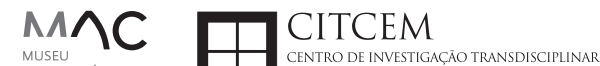
MUSEU
ARQUELLÓGICO
DO CARMO
U.PORTO

FLUP FACULDADE DE LETRAS
UNIVERSIDADE DO PORTO

Apoio

EC para a Ciência 


\section{Índice}

15 Prefácio

José Morais Arnaud

\section{Historiografia e Teoria}

17 Território, comunidade, memória e emoção: a contribuição da história da arqueologia (algumas primeiras e breves reflexões)

Ana Cristina Martins

25 Como descolonizar a arqueologia portuguesa?

Rui Gomes Coelho

41 Arqueologia e Modernidade: uma revisitação pessoal e breve de alguns aspetos da obra homónima de Julian Thomas de 2004

Vítor Oliveira Jorge

57 Dados para a História das Mulheres na Arqueologia portuguesa, dos finais do século XIX aos inícios do século XX: números, nomes e tabelas

Filipa Dimas / Mariana Diniz

73 Retractos da arqueologia portuguesa na imprensa: (in)visibilidades no feminino

Catarina Costeira / Elsa Luís

85 Arqueologia e Arqueólogos no Norte de Portugal Jacinta Bugalhão

101 Vieira Guimarães (1864-1939) e a arqueologia em Tomar: uma abordagem sobre o território e as gentes

João Amendoeira Peixoto / Ana Cristina Martins

115 Os memoráveis? A arqueologia algarvia na imprensa nacional e regional na presente centúria (2001-2019): características, visões do(s) passado(s) e a arqueologia

enquanto marca

Frederico Agosto / João Silva

129 A Evolução da Arqueologia Urbana e a Valorização Patrimonial no Barlavento Algarvio: Os casos de Portimão e Silves

Artur Mateus / Diogo Varandas / Rafael Boavida

\section{Gestão, Valorização e Salvaguarda do Património}

145 O Caderno Reivindicativo e as condições de trabalho em Arqueologia Miguel Rocha / Liliana Matias Carvalho / Regis Barbosa / Mauro Correia / Sara Simões / Jacinta Bugalhão / Sara Brito / Liliana Veríssimo Carvalho / Richard Peace / Pedro Peça / Cézer Santos

155 Os Estudos de Impacte Patrimonial como elemento para uma estratégia sustentável de minimização de impactes no âmbito de reconversões agrícolas Tiago do Pereiro

165 Salvaguarda de Património arqueológico em operações florestais: gestão e sensibilização Filipa Bragança / Gertrudes Zambujo / Sandra Lourenço / Belém Paiva / Carlos Banha / Frederico Tatá Regala / Helena Moura / Jacinta Bugalhão / João Marques / José Correia / Pedro Faria / Samuel Melro

179 Os valores do Património: uma investigação sobre os Sítios Pré-históricos de Arte Rupestre do Vale do Rio Côa e de Siega Verde José Paulo Francisco 
189 Conjugando recursos arqueológicos e naturais para potenciar as visitas ao Geoparque Litoral de Viana do Castelo (Noroeste de Portugal)

Hugo A. Sampaio / Ana M.S. Bettencourt / Susana Marinho / Ricardo Carvalhido

203 Áreas de Potencial Arqueológico na Região do Médio Tejo: Modelo Espacial Preditivo Rita Ferreira Anastácio / Ana Filipa Martins / Luiz Oosterbeek

223 Património Arqueológico e Gestão Territorial: O contributo da Arqueologia para a revisão do PDM de Avis

Ana Cristina Ribeiro

237 A coleção arqueológica do extinto Museu Municipal do Porto - Origens, Percursos e Estudos

Sónia Couto

251 Valpaços - uma nova carta arqueológica

Pedro Pereira / Maria de Fátima Casares Machado

263 Arqueologia na Cidade de Peniche

Adriano Constantino / Luís Rendeiro

273 Arqueologia Urbana: a cidade de Lagos como caso de Estudo Cátia Neto

285 Estratégias de promoção do património cultural subaquático nos Açores. O caso da ilha do Faial

José Luís Neto / José Bettencourt / Luís Borges / Pedro Parreira

297 Carta Arqueológica da Cidade Velha: Uma primeira abordagem

Jaylson Monteiro / Nireide Tavares / Sara da Veiga / Claudino Ramos / Edson Brito /

Carlos Carvalho / Francisco Moreira / Adalberto Tavares

311 Antropologia Virtual: novas metodologias para a análise morfológica e funcional Ricardo Miguel Godinho / Célia Gonçalves

\section{Didáctica da Arqueologia}

327 Como os projetos de Arqueologia podem contribuir para uma comunidade culturalmente mais consciente Alexandra Figueiredo / Claúdio Monteiro / Adolfo Silveira / Ricardo Lopes

337 Educação Patrimonial - Um cidadão esclarecido é um cidadão ativo! Ana Paula Almeida

351 A aproximação da Arqueologia à sala de aula: um caso de estudo no $3^{\circ}$ ciclo do Ensino Básico Luís Serrão Gil

363 Arqueologia 3.o - Pensar e comunicar a Arqueologia para um futuro sustentável Mónica Rolo

377 “Conversa de Arqueólogos" - Divulgar a Arqueologia em tempos de Pandemia Diogo Teixeira Dias

389 Escola Profissional de Arqueologia: desafios e oportunidades Susana Nunes / Dulcineia Pinto / Júlia Silva / Ana Mascarenhas

399 Os Museus de Arqueologia e os Jovens: a oferta educativa para o público adolescente Beatriz Correia Barata / Leonor Medeiros

411 O museu universitário como mediador entre a ciência e a sociedade: o exemplo da secção de arqueologia no Museu de História Natural e da Ciência da Universidade do Porto (MHNC-UP)

Rita Gaspar 
421 Museu de Lanifícios: Real Fábrica de Panos. Atividades no âmbito da Arqueologia Beatriz Correia Barata / Rita Salvado

427 Arqueologia Pública e o caso da localidade da Mata (Torres Novas) Cláudia Manso / Ana Rita Ferreira / Cristiana Ferreira / Vanessa Cardoso Antunes

431 Do sítio arqueológico ao museu: um percurso (também) didático Lídia Fernandes

447 Estão todos convidados para a Festa! E para dançar também... O projecto do Serviço Educativo do Museu Arqueológico do Carmo na $5^{\underline{a}}$ Edição da Festa da Arqueologia Rita Pires dos Santos

459 O “Clã de Carenque”, um projeto didático de arqueologia Eduardo Gonzalez Rocha

469 Mediação cultural: peixe que puxa carroça nas Ruínas Romanas de Troia Inês Vaz Pinto / Ana Patrícia Magalhães / Patrícia Brum / Filipa Santos

481 Didática Arqueológica, experiências do Projeto Mértola Vila Museu Maria de Fátima Palma / Clara Rodrigues / Susana Gómez / Lígia Rafael

\section{Arte Rupestre}

497 Os inventários de arte rupestre em Portugal Mila Simões de Abreu

513 O projeto FIRST-ART - conservação, documentação e gestão das primeiras manifestações de arte rupestre no Sudoeste da Península Ibérica: as grutas do Escoural e Maltravieso Sara Garcês / Hipólito Collado / José Julio García Arranz / Luiz Oosterbeek / António Carlos Silva / Pierluigi Rosina / Hugo Gomes / Anabela Borralheiro Pereira / George Nash / Esmeralda Gomes / Nelson Almeida / Carlos Carpetudo

523 Trabalhos de documentação de arte paleolítica realizados no âmbito do projeto PalæoCôa André Tomás Santos / António Fernando Barbosa / Luís Luís / Marcelo Silvestre / Thierry Aubry

537 Imagens fantasmagóricas, silhuetas elusivas: as figuras humanas na arte do Paleolítico Superior da região do Côa Mário Reis

$55^{1}$ Os motivos zoomórficos representados nas placas de tear de Vila Nova de São Pedro (Azambuja, Portugal) Andrea Martins / César Neves / José M. Arnaud / Mariana Diniz

571 Arte Rupestre do Monte de Góios (Lanhelas, Caminha). Síntese dos resultados dos trabalhos efectuados em 2007-2009 Mário Varela Gomes

599 Gravuras rupestres de barquiformes no Monte de S. Romão, Guimarães, Noroeste de Portugal Daniela Cardoso

613 Círculos segmentados gravados na Bacia do Rio Lima (Noroeste de Portugal): contributos para o seu estudo Diogo Marinho / Ana M.S. Bettencourt / Hugo Aluai Sampaio

631 Equídeos gravados no curso inferior do Rio Mouro, Monção (NW Portugal). Análise preliminar Coutinho, L.M. / Bettencourt, A.M.S / Sampaio, Hugo A.S

645 Paletas na Arte Rupestre do Noroeste de Portugal. Inventário preliminar Bruna Sousa Afonso / Ana M. S. Bettencourt / Hugo A. Sampaio 


\section{Pré-História}

661 O projeto Miño/Minho: balanço de quatro anos de trabalhos arqueológicos Sérgio Monteiro-Rodrigues / João Pedro Cunha-Ribeiro / Eduardo Méndez-Quintas / Carlos Ferreira / Pedro Xavier / José Meireles / Alberto Gomes / Manuel Santonja / Alfredo Pérez-González

677 A ocupação paleolítica da margem esquerda do Baixo Minho: a indústria lítica do sítio de Pedreiras 2 (Monção, Portugal) e a sua integração no contexto regional Carlos Ferreira / João Pedro Cunha-Ribeiro / Sérgio Monteiro-Rodrigues / Eduardo Méndez-Quintas / Pedro Xavier / José Meireles / Alberto Gomes / Manuel Santonja / Alfredo Pérez-González

693 O sítio acheulense do Plistocénico médio da Gruta da Aroeira Joan Daura / Montserrat Sanz / Filipa Rodrigues / Pedro Souto / João Zilhão

703 As sociedades neandertais no Barlavento algarvio: modelos preditivos com recurso aos SIG

Daniela Maio

715 A utilização de quartzo durante o Paleolítico Superior no território dos vales dos rios Vouga e Côa

Cristina Gameiro / Thierry Aubry / Bárbara Costa / Sérgio Gomes / Luís Luís / Carmen Manzano / André Tomás Santos

733 Uma perspetiva diacrónica da ocupação do concheiro do Cabeço da Amoreira (Muge, Portugal) a partir da tecnologia lítica Joana Belmiro / João Cascalheira / Célia Gonçalves

745 Novos dados sobre a Pré-história Antiga no concelho de Palmela. A intervenção arqueológica no sítio do Poceirão I

Michelle Teixeira Santos

757 Problemas em torno de Datas Absolutas Pré-Históricas no Norte do Alentejo Jorge de Oliveira

771 Povoamento pré-histórico nas áreas montanhosas do NO de Portugal: o Abrigo 1 de Vale de Cerdeira Pedro Xavier / José Meireles / Carlos Alves

783 Apreciação do povoamento do Neolítico Inicial na Baixa Bacia do Douro. A Lavra I (Serra da Aboboreira) como caso de estudo Maria de Jesus Sanches

797 O Processo de Neolitização na Plataforma do Mondego: os dados do Sector C do Outeiro dos Castelos de Beijós (Carregal do Sal)

João Carlos de Senna-Martinez / José Manuel Quintã Ventura / Andreia Carvalho / Cíntia Maurício

823 Novos trabalhos na Lapa da Bugalheira (Almonda, Torres Novas) Filipa Rodrigues / Pedro Souto / Artur Ferreira / Alexandre Varanda / Luís Gomes / Helena Gomes / João Zilhão

837 A pedra polida e afeiçoada do sítio do Neolítico médio da Moita do Ourives (Benavente, Portugal)

César Neves

857 Casal do Outeiro (Encarnação, Mafra): novos contributos para o conhecimento do povoamento do Neolítico final na Península de Lisboa.

Cátia Delicado / Carlos Maneira e Costa / Marta Miranda / Ana Catarina Sousa

873 Stresse infantil, morbilidade e mortalidade no sítio arqueológico do Neolítico Final/ Calcolítico ( $4^{\circ}$ e $3^{\circ}$ milénio a.C.) do Monte do Carrascal 2 (Ferreira do Alentejo, Beja) Liliana Matias de Carvalho / Sofia N. Wasterlain 
885 Come together: O Conjunto Megalítico das Motas (Monção, Viana do Castelo) e as expressões Campaniformes do Alto Minho Ana Catarina Basílio / Rui Ramos

899 Trabalhos arqueológicos no sítio Calcolítico da Pedreira do Poio Carla Magalhães / João Muralha / Mário Reis / António Batarda Fernandes

913 O sítio arqueológico de Castanheiro do Vento. Da arquitectura do sítio à arquitectura de um território João Muralha Cardoso

925 Estudo zooarqueológico das faunas do Calcolítico final de Vila Nova de São Pedro (Azambuja, Portugal): Campanhas de 2017 e 2018 Cleia Detry / Ana Catarina Francisco / Mariana Diniz / Andrea Martins / César Neves / José Morais Arnaud

943 As faunas depositadas no Museu Arqueológico do Carmo provenientes de Vila Nova de São Pedro (Azambuja): as campanhas de 1937 a 1967 Ana Catarina Francisco / Cleia Detry / César Neves / Andrea Martins / Mariana Diniz / José Morais Arnaud

959 Análise funcional de material lítico em sílex do castro de Vila Nova de S. Pedro (Azambuja, Portugal): uma primeira abordagem Rafael Lima

971 O recinto da Folha do Ouro 1 (Serpa) no contexto dos recintos de fossos calcolíticos alentejanos

António Carlos Valera / Tiago do Pereiro / Pedro Valério / António M. Monge Soares

\section{Proto-História}

987 Produção de sal marinho na Idade do Bronze do noroeste Português. Alguns dados para uma reflexão

Ana M. S. Bettencourt / Sara Luz / Nuno Oliveira / Pedro P. Simões / Maria Isabel C. Alves / Emílio Abad-Vidal

1001 A estátua-menir do Pedrão ou de São Bartolomeu do Mar (Esposende, noroeste de Portugal) no contexto arqueológico da fachada costeira de entre os rios Neiva e Cávado Ana M. S. Bettencourt / Manuel Santos-Estévez / Pedro Pimenta Simões / Luís Gonçalves

1015 O Castro do Muro (Vandoma/Baltar, Paredes) - notas para uma biografia de ocupação da Idade do Bronze à Idade Média

Maria Antónia D. Silva / Ana M. S. Bettencourt / António Manuel S. P. Silva / Natália Félix

1031 Do Bronze Final à Idade Média - continuidades e hiatos na ocupação de Povoados em Oliveira de Azeméis João Tiago Tavares / Adriaan de Man

1041 As faunas do final da Idade do Bronze no Sul de Portugal: leituras desde o Outeiro do Circo (Beja)

Nelson J. Almeida / Íris Dias / Cleia Detry / Eduardo Porfírio / Miguel Serra

1055 A Espada do Monte das Oliveiras (Serpa) - uma arma do Bronze Pleno do Sudoeste Rui M. G. Monge Soares / Pedro Valério / Mariana Nabais / António M. Monge Soares

1065 São Julião da Branca (Albergaria-a-Velha) - Investigação e valorização de um povoado do Bronze Final

António Manuel S. P. Silva / Paulo A. P. Lemos / Sara Almeida e Silva / Edite Martins de Sá

1083 Do castro de S. João ao Mosteiro de Santa Clara: notícia de uma intervenção arqueológica, em Vila do Conde Rui Pinheiro 
1095 O castro de Ovil (Espinho), um quarto de século de investigação - resultados e questões em aberto

Jorge Fernando Salvador / António Manuel S. P. Silva

1111 O Castro de Salreu (Estarreja), um povoado proto-histórico no litoral do Entre Douro e Vouga

Sara Almeida e Silva / António Manuel S. P. Silva / Paulo A. P. Lemos / Edite Martins de Sá

1127 Castro de Nossa Senhora das Necessidades (Sernancelhe): uma primeira análise artefactual Telma Susana O. Ribeiro

${ }_{1141}$ A cividade de Bagunte. O estado atual da investigação Pedro Brochado de Almeida

1153 Zoomorfos na cerâmica da Idade do Ferro no NW Peninsular: inventário, cronologias e significado Nuno Oliveira / Cristina Seoane

1163 Vasos gregos em Portugal: diferentes maneiras de contar a história do intercâmbio cultural na Idade do Ferro

Daniela Ferreira

1175 Os exotica da necrópole da Idade do Ferro do Olival do Senhor dos Mártires (Alcácer do Sal) no seu contexto regional

Francisco B. Gomes

\section{Antiguidade Clássica e Tardia}

1191 O uso de madeira como combustível no sítio da Quinta de Crestelos (Baixo Sabor): da Idade do Ferro à Romanização Filipe Vaz / João Tereso / Sérgio Simões Pereira / José Sastre / Javier Larrazabal Galarza / Susana Cosme / José António Pereira / Israel Espi

1207 Cultivos de Época Romana no Baixo Sabor: continuidade em tempos de mudança? João Pedro Tereso / Sérgio Simões Pereira / Filipe Santos / Luís Seabra / Filipe Vaz

1221 A casa romana na Hispânia: aplicação dos modelos itálicos nas províncias ibéricas Fernanda Magalhães / Diego Machado / Manuela Martins

1235 As pinturas murais romanas da Rua General Sousa Machado, n. ${ }^{5}$ 1, Chaves José Carvalho

1243 Trás do Castelo (Vale de Mir, Pegarinhos, Alijó) - Uma exploração agrícola romana do Douro

Tony Silvino / Pedro Pereira

1255 A sequência de ocupação no quadrante sudeste de Bracara Augusta: as transformações de uma unidade doméstica Lara Fernandes / Manuela Martins

1263 Os Mosaicos com decoração geométrica e geométrico-vegetalista dos sítios arqueológicos da área do Conuentus Bracaraugustanus. Novas abordagens quanto à conservação, restauro, decoração e datação Maria de Fátima Abraços / Licínia Wrench

1277 “Casa Romana” do Castro de São Domingos (Cristelos, Lousada): Escavação, Estudo e Musealização Paulo André de P. Lemos

1291 A arqueobotânica no Castro de Guifões (Matosinhos, Noroeste de Portugal): O primeiro estudo carpológico

Luís Seabra / Andreia Arezes / Catarina Magalhães / José Varela / João Pedro Tereso 
1305 Um Horreum Augustano na Foz do Douro (Monte do Castelo de Gaia, Vila Nova de Gaia) Rui Ramos

1311 Ponderais romanos na Lusitânia: padrões, formas, materiais e contextos de utilização Diego Barrios Rodríguez

1323 Um almofariz centro-itálico na foz do Mondego

Marco Penajoia

1335 Estruturas romanas de Carnide - Lisboa Luísa Batalha / Mário Monteiro / Guilherme Cardoso

1347 O contexto funerário do sector da "necrópole NO" da Rua das Portas de S. Antão (Lisboa): o espaço, os artefactos, os indivíduos e a sua interconectividade na interpretação do passado Sílvia Loja, José Carlos Quaresma, Nelson Cabaço, Marina Lourenço, Sílvia Casimiro, Rodrigo Banha da Silva, Francisca Alves-Cardoso

${ }_{1361}$ Povoamento em época Romana na Amadora - resultados de um projeto pluridisciplinar Gisela Encarnação / Vanessa Dias

1371 A Arquitectura Residencial em Mirobriga (Santiago do Cacém): contributo a partir de um estudo de caso Filipe Sousa / Catarina Felício

${ }_{1385}$ O fim do ciclo. Saneamento e gestão de resíduos nos edifícios termais de Mirobriga (Santiago do Cacém)

Catarina Felício / Filipe Sousa

1399 Balsa, Topografia e Urbanismo de uma Cidade Portuária Vítor Silva Dias / João Pedro Bernardes / Celso Candeias / Cristina Tété Garcia

1413 No Largo das Mouras Velhas em Faro (2017): novas evidências da necrópole norte de Ossonoba e da sua ocupação medieval Ricardo Costeira da Silva / Paulo Botelho / Fernando Santos / Liliana Nunes

1429 Instrumentos de pesca recuperados numa fábrica de salga em Ossonoba (Faro) Inês Rasteiro / Ricardo Costeira da Silva / Paulo Botelho

1439 A Necrópole Romana do Eirô, Duas Igrejas (Penafiel): intervenção arqueológica de 2016 Laura Sousa / Teresa Soeiro

1457 Ritual, descarte ou afetividade? A presença de Canis lupus familiaris na Necrópole Noroeste de Olisipo (Lisboa)

Beatriz Calapez Santos / Sofia Simões Pereira / Rodrigo Banha da Silva / Sílvia Casimiro / Cleia Detry / Francisca Alves Cardoso

1467 Dinâmicas económicas em Bracara na Antiguidade Tardia Diego Machado / Manuela Martins / Fernanda Magalhães / Natália Botica

1479 Cerâmicas e Vidros da Antiguidade Tardia do Edifício sob a Igreja do Bom Jesus (Vila Nova de Gaia) Joaquim Filipe Ramos

1493 Novos contributos para a topografia histórica de Mértola no período romano e na Antiguidade Tardia Virgílio Lopes

\section{8. Época Medieval}

1511 Cerâmicas islâmicas no Garb setentrional "português": algumas evidências e incógnitas Constança dos Santos / Helena Catarino / Susana Gómez / Maria José Gonçalves / Isabel Inácio / Gonçalo Lopes / Jacinta Bugalhão / Sandra Cavaco / Jaquelina Covaneiro / Isabel Cristina Fernandes / Ana Sofia Gomes 
1525 Contributo para o conhecimento da cosmética islâmica, em Silves, durante a Idade Média Rosa Varela Gomes

1537 Yábura e o seu território - uma análise histórico-arqueológica de Évora entre os séculos VIII-XII José Rui Santos

1547 A encosta sul do Castelo de Palmela - resultados preliminares da escavação arqueológica Luís Filipe Pereira / Michelle Teixeira Santos

1559 A igreja de São Lourenço (Mouraria, Lisboa): um conjunto de silos e de cerâmica medieval islâmica

Andreia Filipa Moreira Rodrigues

1571 O registo material de movimentações populacionais no Médio Tejo, durante os séculos XII-XIII. Dois casos de "sunken featured buildings", nos concelhos de Cartaxo e Torres Novas Marco Liberato / Helena Santos / Nuno Santos

1585 O nordeste transmontano nos alvores da Idade média. Notas para reflexão Ana Maria da Costa Oliveira

1601 Sepulturas escavadas na rocha do Norte de Portugal e do Vale do Douro: primeiros resultados do Projecto SER-NPVD

Mário Jorge Barroca / César Guedes / Andreia Arezes / Ana Maria Oliveira

1619 "Portucalem Castrum Novum" entre o Mediterrâneo e o Atlântico: o estudo dos materiais cerâmicos alto-medievais do arqueossítio da rua de D. Hugo, nํ. 5 (Porto) João Luís Veloso

1627 A Alta Idade Média na fronteira de Lafões: notas preliminares sobre a Arqueologia no Concelho de Vouzela

Manuel Luís Real / Catarina Tente

1641 Um conjunto cerâmico medieval fora de portas: um breve testemunho aveirense Susana Temudo

${ }_{1651}$ Os Lóios do Porto: uma perspetiva integrada no panorama funerário da Baixa Idade Média à Época Moderna em meios urbanos em Portugal

Ana Lema Seabra

1659 O Caminho Português Interior de Santiago como eixo viário na Idade Média Pedro Azevedo

1665 Morfologia Urbana: Um exercício em torno do Castelo de Ourém André Donas-Botto / Jaqueline Pereira

1677 Intervenção arqueológica na Rua Marquês de Pombal/Largo do Espírito Santo (Bucelas, Loures)

Florbela Estêvão / Nathalie Antunes-Ferreira / Dário Ramos Neves / Inês Lisboa

1691 O Cemitério Medieval do Poço do Borratém e a espacialidade funerária na cidade de Lisboa Inês Belém / Vanessa Filipe / Vasco Noronha Vieira / Sónia Ferro / Rodrigo Banha da Silva

1705 Um Espaço Funerário Conventual do séc. XV em Lisboa: o caso do Convento de São Domingos da Cidade Sérgio Pedroso / Sílvia Casimiro / Rodrigo Banha da Silva / Francisca Alves Cardoso

\section{9. Época Moderna e Contemporânea}

1721 Arqueologia Moderna em Portugal: algumas reflexões críticas em torno da quantificação de conjuntos cerâmicos e suas inferências históricas e antropológicas Rodrigo Banha da Silva / André Bargão / Sara da Cruz Ferreira

1733 Faianças de dois contextos entre os finais do século XVI e XVIII do Palácio dos Condes de Penafiel, Lisboa

Martim Lopes / Tomás Mesquita 
1747 Um perfil de consumo do século XVIII na foz do Tejo: O caso do Mercado da Ribeira, Lisboa Sara da Cruz Ferreira / Rodrigo Banha da Silva / André Bargão

1761 Os Cachimbos dos Séculos XVII e XVIII do Palácio Mesquitela e Convento dos Inglesinhos (Lisboa)

Inês Simão / Marina Pinto / João Pimenta / Sara da Cruz Ferreira / André Bargão / Rodrigo Banha da Silva

1775 "Tomar os fumos da erua que chamão em Portugal erua sancta». Estudo de Cachimbos provenientes da Rua do Terreiro do Trigo, Lisboa

Miguel Martins de Sousa / José Pedro Henriques / Vanessa Galiza Filipe

1787 Cachimbos de Barro Caulínitico da Sé da Cidade Velha (República de Cabo Verde)

Rodrigo Banha da Silva / João Pimenta / Clementino Amaro

1801 Algumas considerações sobre espólio não cerâmico recuperado no Largo de Jesus (Lisboa) Carlos Boavida

1815 Adereços de vidro, dos séculos XVI-XVIII, procedentes do antigo Convento de Santana de Lisboa (anéis, braceletes e contas)

Joana Gonçalves / Rosa Varela Gomes / Mário Varela Gomes

1837 Da ostentação, luxo e poder à simplicidade do uso quotidiano: arqueologia e simbologia de joias e adornos da Idade Moderna Portuguesa Jéssica Iglésias

1849 Os amuletos em Portugal - dos objetos às superstições: o coral vermelho Alexandra Vieira

1865 Cerâmicas de Vila Franca de Xira nos séculos XV e XVI Eva Pires

1879 «Não passa por teu o que me pertence». Marcas de individualização associadas a faianças do Convento de Nossa Senhora de Aracoeli, Alcácer do Sal Catarina Parreira / Íris Fragoso / Miguel Martins de Sousa

1891 Cerâmica de Leiria: alguns focos de produção

Jaqueline Pereira / André Donas-Botto

1901 Os Fornos na Rua da Biquinha, em Óbidos Hugo Silva / Filipe Oliveira

1909 A casa de Pêro Fernandes, contador dos contos de D. Manuel I: o sítio arqueológico da Silha do Alferes, Seixal (século XVI) Mariana Nunes Ferreira

1921 O Alto da Vigia (Sintra) e a vigilância e defesa da costa Alexandre Gonçalves / Sandra Santos

1937 O contexto da torre sineira da Igreja de Santa Maria de Loures Paulo Calaveira / Martim Lopes

1949 A Necrópole do Hospital Militar do Castelo de São Jorge e as práticas funerárias na Lisboa de Época Moderna Susana Henriques / Liliana Matias de Carvalho / Ana Amarante / Sofia N. Wasterlain

1963 SAND - Sarilhos Grandes Entre dois Mundos: o adro da Igreja e a Paleobiologia dos ossos humanos recuperados

Paula Alves Pereira / Roger Lee Jesus / Bruno M. Magalhães

1975 Expansão urbana da vila de Cascais no século XVII e XVIII: a intervenção arqueológica na Rua da Vitória no 15 a 17

Tiago Pereira / Vanessa Filipe

1987 Novos dados para o conhecimento do Urbanismo de Faro em época Moderna Ana Rosa 
1995 Um exemplo de Arqueologia Urbana em Alcoutim: o Antigo Edifício dos CTT Marco Fernandes / Marta Dias / Alexandra Gradim / Virgílio Lopes / Susana Gómez Martínez

2007 Palácio dos Ferrazes (Rua das Flores/Rua da Vitória, Porto): a cocheira de Domingos Oliveira Maia

Francisco Raimundo

2021 As muitas vidas de um edifício urbano: História, Arqueologia e Antropologia no antigo Recreatório Paroquial de Penafiel Helena Bernardo / Jorge Sampaio / Marta Borges

2035 O convento de Nossa Senhora da Esperança de Ponta Delgada: o contributo da arqueologia para o conhecimento de um monumento identitário João Gonçalves Araújo / N’Zinga Oliveira

2047 Arqueologia na ilha do Corvo... em busca da capela de Nossa Senhora do Rosário Tânia Manuel Casimiro / José Luís Neto / Luís Borges / Pedro Parreira

2059 Perdidos à vista da Costa. Trabalhos arqueológicos subaquáticos na Barra do Tejo Jorge Freire / José Bettencourt / Augusto Salgado

2071 Arqueologia marítima em Cabo Verde: enquadramento e primeiros resultados do projecto CONCHA

José Bettencourt / Adilson Dias / Carlos Lima / Christelle Chouzenoux / Cristóvão Fonseca / Dúnia Pereira / Gonçalo Lopes / Inês Coelho / Jaylson Monteiro / José Lima / Maria Eugénia Alves / Patrícia Carvalho / Tiago Silva

2085 Trabalhos arqueológicos na Cidade Velha (Ribeira Grande de Santiago, Cabo Verde): reflexões sobre um projecto de investigação e divulgação patrimonial André Teixeira / Jaylson Monteiro / Mariana Mateus / Nireide Tavares / Cristovão Fonseca / Gonçalo C. Lopes / Joana Bento Torres / Dúnia Pereira / André Bargão / Aurélie Mayer / Bruno Zélie / Carlos Lima / Christelle Chouzenoux / Inês Henriques / Inês Pinto Coelho / José Lima / Patrícia Carvalho / Tiago Silva

2103 A antiga fortificação de Quelba / Khor Kalba (E.A.U.). Resultados de quatro campanhas de escavações, problemáticas e perspectivas futuras Rui Carita / Rosa Varela Gomes / Mário Varela Gomes / Kamyar Kamyad

2123 Colónias para homens novos: arqueologia da colonização agrária fascista no noroeste ibérico Xurxo Ayán Vila / José Mạ . Señorán Martín 


\title{
A COLEÇÃO ARQUEOLÓGICA DO EXTINTO MUSEU MUNICIPAL DO PORTO - ORIGENS, PERCURSOS E ESTUDOS
}

\author{
Sónia Couto ${ }^{1}$
}

\begin{abstract}
RESUMO
O artigo aqui apresentado tem como propósito dar a conhecer a coleção arqueológica do extinto Museu Municipal do Porto, contextualizando-a na história deste museu e como foi constituída, colocando em evidência o importante papel de Rocha Peixoto neste processo.

O percurso desta coleção foi complexo e caracterizado por sucessivas transições entre museus e outros espaços não museológicos, deparando-se com condições adversas no que respeita à conservação, estudo e inventariação da mesma, até chegar ao seu depósito legal que é o Museu Nacional Soares dos Reis. Após a saída da maioria da coleção arqueológica deste museu, a sua dispersão prosseguiu, desconhecendo-se onde se encontram depositados vários objectos até aos dias de hoje.

Palavras-chave: Museu Municipal do Porto, Arqueologia, Rocha Peixoto, Museu Nacional Soares dos Reis, Museu de Etnografia, História do Douro Litoral.
\end{abstract}

\begin{abstract}
The article presented here aims to make known the archaeological collection of the extinct Municipal Museum of Porto, contextualizing it in the history of this museum and how it was constituted, highlighting the important role of Rocha Peixoto in this process.

The route of this collection was complex and characterized by successive transitions between museums and other non-museological spaces, facing adverse conditions regarding to its conservation, study and inventory, until reaching its legal deposit, which is the Museu Nacional Soares dos Kings. After the majority of the archaeological collection left this museum, its dispersion continued, it is unknown where several objects are deposited until today.

Keywords: Museu Municipal do Porto, Archeology, Rocha Peixoto, Museu Nacional Soares dos Reis, Museu de Etnografia, História do Douro Litoral.
\end{abstract}

\section{ORIGEM E HISTÓRIA DO MUSEU MUNICIPAL DO PORTO E DA SUA COLEÇÃO ARQUEOLÓGICA}

O Museu Municipal do Porto foi o primeiro museu municipal do país, tendo a sua coleção inicial como base o fundo do Museu Allen (constituído em 1836), que após o seu encerramento pela morte do seu fundador João Allen em 1848, foi colocado a leilão em hasta pública, tendo sido adquirido em 1850 pela Câmara Municipal do Porto.

Da coleção Allen fazia parte um vasto espólio que ia desde pintura, escultura, história natural, mineralogia, geologia, malacologia, etnografia, arqueo- logia, artes decorativas, curiosidades industriais, paramentaria religiosa, numismática, etc. Ele como grande coleccionador e admirador das civilizações clássicas, adquiriu nas suas várias viagens diversas peças arqueológicas, sobretudo oriundas de Roma e Pompeia. À data da aquisição do acervo do Museu Allen pela autarquia do Porto, constava da seção de arqueologia uma pequena colecção egípcia (composta por 8 peças entre estatuetas, amuletos e um escaravelho); uma colecção de vasos gregos (composta por 15 peças), uma colecção de 10 lucernas itálicas, uma estatueta em terracota, um sarcófago romano e ainda alguns fragmentos de mosaico e olarias romanas (Santos, 2005, pp. 99-105) .

1. Arqueóloga/Investigadora independente; sonia.couto@gmail.com 
Com a aquisição do acervo do Museu Allen e devido à falta de instalações para o novo museu, a Câmara Municipal do Porto decide alugar à família Allen as instalações onde o seu museu estava instalado na Rua da Restauração (Figura 1) e é assim aberto no mesmo espaço o Museu Municipal do Porto, inaugurado a 11 de Abril de 1852.

Inicialmente teve a designação de Novo Museu Portuense, conforme consta no Regulamento Interno do Museu datado de 1853. O museu esteve fechado durante um período para obras de reabilitação, reabrindo ao público a 30 de Janeiro de 1853 . A partir de 1858 passou a designar-se Museu Municipal do Porto. A sua direção foi assumida por Eduardo Augusto Allen, um dos filhos do fundador do Museu Allen, que esteve em funções entre 1852 e 1899 (Santos, 2005, pp. 100-101).

Em meados de 1860, a sociedade portuense vai dar início a debates e polémicas na imprensa escrita sobre as funções e a missão de um museu municipal, obrigando a Câmara a apresentar uma posição pública em relação ao seu museu. Apesar de todos estes problemas este continuava a ter sucesso, apresentando um elevado número de visitantes.

O surgimento da Sociedade Carlos Ribeiro no Porto em 1887, composta por personalidades como Ricardo Severo, Rocha Peixoto, Fonseca Cardoso entre outros, em muito veio fomentar estas críticas ao museu, sobretudo por Rocha Peixoto que nomeou uma comissão promovida por esta sociedade, da qual ele também fazia parte, para estudar e reorganizar o Museu Municipal do Porto (MMP) e a sua instalação em edifício próprio.

As más condições de conservação do edifício da Rua da Restauração, aliado às lacunas relativamente à acomodação dos quadros, a iluminação deficiente, entre outros problemas, conduziu a que o museu encerrasse por algum tempo para obras de beneficiação (Almeida, 2006-2007 pp. 47-50).

É precisamente neste período que Rocha Peixoto assume a direção deste Museu, onde esteve entre 1900 e 1909. Com a sua entrada introduziu-se uma nova dinâmica museológica, tendo contribuído substancialmente para o enriquecimento da coleção do Museu, com particular destaque para a coleção arqueológica, quer por doações, aquisições e até mesmo pela troca de objetos entre museus municipais, prática comum na época. Foi aliás da sua responsabilidade o estímulo ao intercâmbio científico e à prática das boas relações entre os museus nacionais.
Nos livros de registos de doações e compras de espólio para o museu, constam várias aquisições realizadas por Rocha Peixoto. Para isso muito contribuiu o facto de ele acompanhar de perto a investigação arqueológica da época, sobretudo em sítios arqueológicos do norte do país, o que lhe permitiu enriquecer o acervo do museu. Do espólio incorporado por ele, destacam-se lápides epigráficas, cerâmicas, moedas, machados de bronze, etc. Na região do grande Porto são vários os sítios arqueológicos onde Rocha Peixoto escavou e recolheu espólio para o MMP, como por exemplo no castro de Laúndos e na villae romana de Vila Mendo na Póvoa de Varzim, de onde proveio uma valiosa coleção de joias proto-históricas que figuram ainda hoje na sala de exposição permanente de ourivesaria do MNSR (Rocha Peixoto, 1908, p.4); o Castro de Guifões em Matosinhos, de onde vieram um sarcófago medieval, uma lucerna, uma urna incineradora em vidro romano, cerâmicas e mós, elementos que constam actualmente das seções de Lapidária e vidros do Museu Nacional Soares dos Reis (MNSR). Os vidros romanos já foram aliás estudados por Jorge e Adília Alarcão (Alarcão, 1964, pp. 73-79).

São vários os investigadores que neste período realizavam escavações arqueológicas e ofereciam o espólio aos museus, o MMP também não fugiu à regra, aparecendo ofertas de nomes conhecidos da nossa arqueologia como José Fortes, José de Pinho, Ricardo Severo, José Leite Vasconcelos e o próprio Rocha Peixoto (Figura 2 e 3 ).

Foi ainda da autoria de Rocha Peixoto em 1902, o Guia do Museu Municipal do Porto, com o inventário das coleções que este museu possuía, estando o mesmo dividido pelas seções de Arqueologia, Etnografia, Arte Industrial, Pintura, Escultura, Cerâmica, Numismática Nacional e Estrangeira (Peixoto, 1902, pp.7-24).

Apesar das várias tentativas de Rocha Peixoto no sentido de obter um espaço novo adequado à dimensão das coleções do museu, este acabaria por encerrar as instalações na Rua da Restauração a 21 de Julho de 1905, transferindo-se para a dependência da Biblioteca Pública Municipal do Porto, localizada em São Lázaro no edifício do extinto Convento de Santo António da cidade, onde já funcionava também o Museu Portuense e a Escola de Belas Artes do Porto. Nas novas instalações e face às circunstâncias do espaço, Rocha Peixoto cria a seção de Lapidária, aproveitando o claustro do convento para aí expor a 
coleção de peças em pedra como capitéis, estátuas, sarcófagos, restos arquitetónicos, escudos de armas, estelas etc. Rocha Peixoto enriqueceu ainda o património artístico do museu, sobretudo com os objetos, que por depósito legal no museu, vieram dos extintos conventos do Porto e Vila do Conde, tais como painéis de azulejos que podemos ver expostos até aos dias de hoje neste edifício.

Entre 1905 e 1906 Rocha Peixoto levou a cabo várias iniciativas no sentido de valorizar Museu, enviando fotografias das diversas colecções para vários museus do país, e distribuiu uma comunicação aos beneméritos da arqueologia, relatando o estado do museu e apelando à cooperação, tendo mesmo conseguido mobilizar o ilustre Prof. Schulten para uma visita ao Porto em 1906, na companhia de Mendes Correia, José Fortes e Ricardo Severo, que se debruçaram atentamente a visitar a colecção de arqueologia, dando particular destaque à famosa Pedra dos Namorados. (Almeida, 2008, pp. 110-113)

Com a morte de Rocha Peixoto em 1909, o museu entra num processo de estagnação e ruína, sabendo-se que em 1912 o MMP se encontrava encerrado, estando apenas exposta ao público a seção lapidar instalada nos claustros do mosteiro. Em 1913 o museu reabre e a sua direção passa a ser a mesma da Biblioteca Pública Municipal do Porto. José Pereira de Sampaio Bruno passa a exercer o lugar de conservador do museu até 1914, data do seu falecimento, sendo desta forma substituído por João Grave, que também viria a falecer em 1919. É neste ano que numa sessão da Comissão Administrativa da Câmara Municipal do Porto, o seu presidente Dr. Armando Marques Guedes apoiou a remodelação do Museu Municipal, sob a proposta de A. J. Paiva Manso, tornando este estabelecimento autónomo da Biblioteca Pública Municipal. Assim, quem acaba por assumir a direção do MMP é Júlio Brandão, cargo que irá exercer até 1939, ano em que se aposentou (Couto, 2011, pp. 32-33).

O cargo de conservador do museu é assumido por Pedro Vitorino de 1922 até 1933, passando a partir deste ano e até 1938 a exercer o cargo de vice-diretor. A sua ida para o museu no entanto não foi suficiente para resolver os problemas com que este se deparava, mesmo tendo feito tentativas de seguir as matrizes definidas anteriormente por Rocha Peixoto.

A sua ação em prol do museu era bem evidente, tanto que Pedro Vitorino fez parte em 1929 do grupo fundador dos Amigos do Museu Municipal do
Porto, cujos objetivos eram sobretudo o enriquecimento das coleções e a promoção da investigação, exposições, conferências e publicações na defesa do património da cidade do Porto, em colaboração com outros museus. Porém, a inexistência de condições para o progresso do museu levou à sua estagnação e consequente abandono, mantendo-se inalterado até Novembro de 1938 quando foi extinto.

\section{O FIM DO MUSEU MUNICIPAL DO PORTO E A INCORPORAÇÃO DO SEU ACERVO NO MUSEU NACIONAL SOARES DOS REIS}

Com a nomeação do Museu Soares dos Reis a museu nacional e a aquisição de um novo espaço para a sua instalação, o Palácio dos Carrancas, é ordenado através do decreto-lei no 27:878 de 21 de Julho de 1937 que todo o espólio do Museu Municipal do Porto fosse incorporado a título de depósito no Museu Nacional Soares dos Reis, precedido de inventário e identificação.

O Museu Municipal do Porto tinha apenas uma série de inventariações fragmentárias de algumas coleções, nomeadamente um inventário parcial datado de 1920, como nos dá conta o Relatório que o Museu Municipal do Porto apresentou ao presidente da C.M. Porto Dr. Mendes Corrêa em 1939, no qual é referido ainda que o museu possuía inúmeras obras de arte por inventariar que se encontravam dispersas em arrecadações do museu e nas águas furtadas do edifício da Câmara Municipal do Porto da altura. (Almeida, 2008, pp. 129-130)

A desorganização em que se encontrava o MMP, foi aliás denunciada e contestada por parte de Pedro Vitorino na sua obra "Brandão o coveiro do Museu Municipal do Porto", publicada em 1939, após a realização deste inventário, colocando em causa a direção do museu por parte de Júlio Brandão e tecendo duras críticas ao mau estado em que as coleções se encontravam, afirmando mesmo que muitas delas estavam ocultas em armários. Referiu ainda as medidas tomadas por ele sobretudo no que respeita ao regresso de objetos e coleções que se encontravam nos depósitos da C. M. Porto, em locais em risco de ruína, afirmando também que foi da sua iniciativa a criação de etiquetas e de livros de registo dos objetos que se encontravam no museu. Por este motivo, foi necessário realizar um exaustivo inventário de todo o seu acervo, que pela sua dimensão e a escassez de recursos humanos foi demorado, tendo sido 
desenvolvido entre 1938/1940. Este trabalho de inventariação foi materializado em 20 volumes divididos por várias secções desde pintura, escultura, desenho, gravura, fotografia, etnografia, numismática, arqueologia e lapidária, ourivesaria, cerâmica, cristais e vidros, objectos arqueológicos, etc. (Vitorino, 1939, pp. 5-10).

O processo de transferência de todo o espólio do MMP para o Museu Nacional Soares dos Reis decorreu entre 13 de Junho de 1940 e 5 de Abril de 1941, sendo que a coleção arqueológica só foi incorporada em 1941. O Museu Nacional Soares dos Reis abriu provisoriamente as suas portas ao público no Palácio dos Carrancas a 4 Julho 1940 com uma exposição de obras de Soares dos Reis, apesar da sua inauguração oficial ter ocorrido apenas em 1942.

Apesar de se tratar de um museu direcionado para a arte, este acabaria por assumir um carácter misto, passando a integrar uma sala de arqueologia (Figura 4) como nos dá conta o catálogo/guia do MNSR datado de 1952, que faz referência aos objetos expostos nesta sala e nos jardins arqueológicos, entre eles o famoso sarcófago romano da coleção do João Allen/ MMP. (1952², pp.5-19)

\section{A COLEÇÃO ARQUEOLÓGICA DO MMP}

Este acervo quando transitou para o MNSR manteve a mesma organização que possuía no extinto MMP, por esse motivo encontramos objetos arqueológicos dispersos por várias secções. Por exemplo na seção de Ourivesaria encontra-se um conjunto de jóias proto-históricas em ouro (um colar, um par de aros, um par de brincos, dois pares de arrecadas) e ainda o escaravelho em ouro egípcio; na secção de Vidros existem frascos e uma urna cinerária em vidro romano, na secção de Lapidária composta por vários elementos como aras e estelas romanas, sarcófagos, mós, pedras com inscrições, brasões e vários elementos arquitetónicos provenientes de conventos e mosteiros extintos, constam um total de 139 peças no inventário do MMP. A seção de Numismática possui coleções de moedas de cronologias variadas, que na sua maioria transitaram para o Gabinete de Numismática da C.M. Porto.

Da seção de objectos arqueológicos do inventário do MMP realizado entre 1938-1940, constam cerca de 271 itens relativos a materiais arqueológicos variados, sendo que alguns estão agrupados por lotes, caixotes, sacos com vários objetos, tornado ainda mais difícil perceber com precisão o número exacto de objetos. Esta seção é composta predominantemente por materiais cerâmicos de cronologias da idade do ferro e romanização, sobretudo utensílios em cerâmica, alguns exemplares de sigilattas e uma candela. Pode-se ainda encontrar fragmentos de ânforas, mosaicos romanos, azulejos, uma ossada humana, pesos de tear e cossoiros, pesos de rede, machados e outros objetos líticos da pré-história, materiais em bronze como machados, uma fíbula, um bracelete, um amuleto, uma ponta de lança. Fazem ainda parte desta seção de arqueologia uma colecção de vasos gregos; um conjunto de estatuetas egípcias, um conjunto de lucernas itálicas e ainda uma enigmática estatueta em terracota, todos estes da colecção Allen.

A maioria dos materiais é proveniente de estações arqueológicas do Norte do país, como por exemplo Castro de São Félix, Villa de S. Martin Vaz e Estela na Póvoa de Varzim, estudadas por José Fortes (1905-19o8, pp. 604-618); Necrópole do Bairral em Baião estudada por Ricardo Severo (1906, pp. 417-430); Necrópole de Vila Verde, Necrópole da Lomba, Necrópole de Laboriz, Necrópole de Ataúdes e Necrópole de Vilarinho todas localizadas em Amarante e estudadas por Helena Portela (1998, pp.); o Castro da Agra de S. Brás em Frazão, Paços de Ferreira estudada por Manuel Vieira Dinis (1976, pp. 217-222); o Castro de Guifões, Matosinhos; Ponte de Lima; Trofa; Barcelos; Valongo; Póvoa de Lanhoso; Valença, Viana do Castelo; Melgaço, Bragança. Aparecem no entanto materiais de outras regiões do país como o Castro de Ossela em Oliveira de Azeméis onde Rocha Peixoto também realizou escavações, de Santarém, Evoramonte, Castelo de Vide, Alentejo, Salvaterra de Magos e também de Pontevedra e Mérida em Espanha.

Quando se iniciou esta investigação no âmbito da minha dissertação de mestrado desenvolvida entre 2009 e 2011, encontrava-se na secção de Diversos das reservas do Museu Nacional Soares dos Reis um conjunto de peças arqueológicas pertencentes ao Museu Municipal do Porto entre elas a coleção egípcia estudada por Luis Manuel Araújo (1995, pp. 7-20), a de vasos gregos estudada por Rui Morais e Maria Helena Rocha-Pereira (2008, pp. 1-72) e de lucernas itálicas também estudadas por Rui Morais (2008-2009, pp. 65-79) e ainda 23 objetos arqueológicos de cronologias, materiais e tipologias diferentes, que se encontravam por estudar. Estes últimos, na maioria não possuía número de inventário do 
MMP, alguns apresentavam etiquetas coladas com a sua proveniência e quem ofereceu, outros tinham escrito directamente no objecto a tinta uma numeração que se assumiu ser o número de inventário do MMP e nos restantes não existia qualquer informação. Como tal foi necessário realizar um exercício de cruzamento de informação, nomeadamente com o inventário realizado entre 1938/1940, o Guia do MMP de 1902 e documentação como livros de registo de entrada de espólio existentes no arquivo do MMP. Apenas para oito deles conseguiu-se informação precisa de que eram provenientes do MMP e fazer corresponder com o número de inventário: um machado de pedra, um machado pedra polido; um peso de tear (Figura 7); uma Ampulla de duas asas simétricas; um amuleto Figas Phallus (Figura 6), um bracelete aberto e um corpo de fíbula todos em bronze e ainda uma estatueta celtibérica em terracota. Dos restantes objectos, alguns deles não possuem número de inventário, apresentando apenas etiquetas com indicação do sítio de proveniência e/ou quem ofereceu, colocando-se a hipótese de pertencerem ao MMP, visto serem oriundos de escavações arqueológicas realizadas no inicio do século XX, outros não têm qualquer informação. Este lote é composto por: uma lâmina de sílex (Figura 5); um prato, uma bilha, um copo e um jarro de cerâmica romana, um fragmento de machado polido sob seixo; um núcleo de seixo em quartzito; um machado polido em anfibolito; uma enxó em silimanite; um jarro trilobado romano; um copo cerâmica romana; um prato cerâmica romana; uma bilha de cerâmica romana; uma estatueta em bronze. Foi ainda contemplado neste estudo um conjunto de cinco objetos arqueológicos que fazem parte da coleção do Museu Nacional Soares dos Reis, que aqui foram incorporados nos dos finais da década de 40 do século XX, sendo eles: um púcaro e uma tigela de cerâmica romana; uma estatueta de Marte, um cabo de Pátera e um machado de talão todos em bronze e ainda uma ânfora localizada na seção de cerâmica posteriormente à entrega da minha dissertação de mestrado, por esse motivo foi apenas estudada posteriormente e incluída na exposição realizada em 2012 neste museu. Estas incorporações no MNSR não são surpreendentes ocorrerem visto que após o encerramento do MMP não existia outro museu no Porto para acolher este tipo de espólio.

\section{PROCESSO DE TRANSIÇÃO DA COLEÇÃOMARQUEOLÓGICA DO MUSEU NACIONAL SOARES DOS REIS PARA O MUSEU DE ETNOGRAFIA E HISTÓRIA DO DOURO LITORAL}

O processo de dispersão deste espólio não ficaria por aqui, pois sendo o Museu Nacional Soares dos Reis um museu de arte e com a abertura em 1945 do Museu de Etnografia e História do Douro Litoral, foi autorizado em 1955 por despacho da presidência da C. M. Porto datado de 03-09-1955, através do ofício $2532 / 55$, que se transferisse o espólio da secção de arqueologia provenientes do Museu Municipal do Porto para o Museu de Etnografia e História do Douro Litoral, desde que das mesmas ficasse a constar que pertenciam ao património municipal. Da lista de materiais que transitaram constavam todos os objetos da seção de arqueologia do inventário do MMP, com exceção das 3 coleções de Allen, respetivamente a de vasos gregos, a egípcia, a de lucernas e ainda uma estatueta celtibérica em terracota. Permaneceram também no MNSR vários materiais em bronze como um amuleto Figas Phallus, um bracelete aberto e um corpo de fíbula, bem como todos os objetos arqueológicos das seções de Ourivesaria, Lapidária e Vidros. Foram ainda para o Museu de Etnografia e História do Douro Litoral da secção de Lapidária, subsecção de Avulsos: 1 caixote com seixos marítimos; um caixote com fragmentos de ânforas e cântaros; 13 caixotes com fragmentos cerâmicos; um caixote com uma ossada humana; um pacote com azulejos e 11 peças de mosaicos.

Neste processo de transferência, coloca-se a hipótese de alguns dos objetos terem ficado no MNSR por razões que se desconhece, nomeadamente alguns dos referidos anteriormente estudados na minha dissertação de mestrado que faziam parte do inventário do MMP.

O Museu de Etnografia e História do Douro Litoral como refere Maria do Rosário Pestana manteve-se em funcionamento entre 1945 e 1959. "Entre 1948 e 1957 (datas disponíveis nos livros de tombo), o Museu mais que duplicou o seu fundo, em parte devido a depósitos ou transferências de outras instituições: Instituto de Antropologia da Universidade do Porto, Museu Nacional Soares dos Reis, Câmara Municipal do Porto, comissões venatórias regionais do Centro e do Norte, etc."(Pestana, 2009, p.6). 
Em 1959 com a extinção das autarquias provinciais, o museu foi reformulado, passando a designar-se $\mathrm{Mu}$ seu de Etnologia do Porto e dirigido por Fernando de Castro Pires de Lima. Depois de 1970, as instalações do Museu começaram a degradar-se com repercussões nas condições de conservação das coleções.

Existem referências sobre o estado de degradação em que o Museu de Etnografia e História do Douro Litoral se encontrava já na década de 6o, como nos dá conta Joaquim Neves dos Santos sobre o mau estado de conservação de um mosaico romano proveniente de Lavra que ali se encontrava com reflexos particularmente negativos nas condições de conservação das suas colecções (1963, pp. 11-13).

Fernando Lanhas assume a sua direção entre 1973 e 1993. Em 1989, o museu passa a ser tutelado do IPPC e em 1991 pelo IPM, vindo a ser encerrado ao público em 1992, após um incêndio que sofreu que conduziu a um avançado estado de ruína do imóvel (Pestana, 2009, p. 11).

Pode-se afirmar que a transferência da coleção arqueológica do MMP para o Museu de Etnografia e História do Douro Litoral, deu início a um processo de desmembramento desta coleção, que se irá prolongar até 2013.

\section{O ENCERRAMENTO DO MUSEU DE ETNOLOGIA DO PORTO E O INÍCIO DO PROCESSO DE DISPERSÃO DA COLEÇÃO ARQUEOLÓGICA DO MUSEU MUNICIPAL DO PORTO}

Na sequência do seu encerramento, o IPM toma medidas no sentido de salvaguardar o espólio do museu. Assim, numa primeira fase ordena o depósito das suas coleções em diversos museus com vista à sua proteção, numa segunda fase foram efetuadas com a colaboração da DGEMN, obras nas coberturas e na fachada do Palácio, tendo sido realizado ainda numa terceira fase um processo de sistematização do seu inventário (Pestana, 2209, p. 11).

É desta forma que se dá continuidade à dispersão do espólio arqueológico do Museu Municipal do Porto, pois até hoje apesar das várias tentativas levadas a cabo por várias pessoas e entidades, nunca foi facultada uma lista com a indicação dos objetos do MMP que saíram do Museu de Etnologia e em que museus ou locais foram depositados.

Do que se conseguiu apurar, sabe-se que quase todo o espólio pertencente ao Museu de Etnologia, foi depositado em vários museus, entre eles o Museu D. Diogo de Sousa, Museu dos Biscainhos, Museu da Nazaré, Museu Municipal de Penafiel, Museu Municipal Póvoa de Varzim, entre outros e uma parte foi enviada para o quartel de São Braz no Porto, cujo edifício também se encontrava em mau estado, tendo o telhado entretanto desabado em cima de parte das coleções que ali se encontram. Até ao momento sabe-se que este edifício se encontra encerrado e sem acesso.

No palacete de S. João Novo ficou ainda a biblioteca, o arquivo, uma parte da coleção de museografia e também alguns caixotes com espólio, visto não se ter decidido para onde iriam. Desde este período (anos 9o do século XX) até 2012, o estado de degradação do palacete foi aumentando de forma drástica. (Soares, 2016, pp. 149-155)

A investigação do percurso que a coleção arqueo-lógica do Museu Municipal do Porto tomou desde que foi incorporada no Museu Nacional Soares dos Reis, iniciou-se como já se referiu anteriormente através da dissertação de mestrado desenvolvida entre 2009-2011.

A investigação desenvolvida revestiu-se de várias condicionantes, por um lado a impossibilidade ter acesso ao Museu de Etnologia por estar encerrado, por outro não possuir informação relativa ao espólio que lá existia e em que museus tinha sido depositado após o seu encerramento.

Ao tentar perceber esta coleção e o seu percurso, através da consulta dos escassos documentos com informações concretas sobre a mesma e o cruzamento dessas mesmas fontes, conduziram a uma série de dúvidas, pois rapidamente se pode perceber a inexistência de inventários completos e rigorosos, pautados por incorreções que induziram em erro algumas das suposições assumidas neste trabalho.

Apenas em 2012 quando é decidido pela tutela a retirada do espólio que ainda restava no palacete onde estava instalado o Museu de Etnologia do Porto, processo no qual é delegado ao MNSR a responsabilidade da recolha do espólio que pertencia ao Museu Municipal do Porto que ainda lá existisse, é que se constata que uma parte do espólio arqueológico que tinha sido para ali transferido em 1957 vindo do MNSR ainda lá se encontrava e em muito mau estado de conservação.

Nesta campanha de resgate do espólio realizada em 2012, são trazidos para o MNSR um total de 44 objetos cerâmicos de cronologia na sua maioria romana, 
40 dos quais faziam parte do Inventário do Museu Municipal do Porto (Figuras 8 e 10).

Na sequência da vinda deste espólio, foi-me endereçado o convite pelo MNSR para continuar o estudo desta coleção, tentando recuperar assim o acervo arqueológico do Museu Municipal do Porto e realizar uma inventariação do mesmo, de forma a se tentar localizar o paradeiro dos materiais em falta.

Em 2013 são ainda recuperados cerca de 35 objetos que ainda se encontravam perdidos nas instalações do Museu de Etnologia, estes na sua maioria composto por materiais líticos e em bronze (Figura 9). Pelas escassas indicações de numeração de inventário, percebe-se que a maioria deles também pertence ao MMP.

Todos estess objectos resgatados em 2012 e 2013 foram alvo de todo um processo de limpeza profunda, consolidação e algum restauro pelo Museu D. Diogo de Sousa em Braga, dado o estado avançado de degradação em que se encontravam, consequência do seu abandono durante décadas nesse espaço.

Mais uma vez por razões desconhecidas, percebe-se que a coleção arqueológica do Museu Municipal do Porto tinha voltado a ser desmembrada, ficando alguns objetos ali perdidos e outros incorporados em museus tais como o D. Diogo de Sousa, como nos dão conta os diversos trabalhos de investigação realizados, nos quais fazem referência a espólio do MMP que se encontra depositado presentemente no Museu D. Diogo de Sousa. Alguns desses estudos contemplam por exemplo um conjunto de cerca de 20 machados em bronze de várias regiões do norte de Portugal (Bottaini,.Giardino, C. \& Paternoster, 2012, pp.19-34); um conjunto de 17 peças cerâmicas romanas das necrópoles da Lomba e Laboriz localizadas em Amarante, estudadas por Helena Portela (1998, pp. 12-97).

Com base nestes trabalhos, começa-se a perceber que uma parte significativa do espólio arqueológico do MMP poderia estar depositado no Museu D. Diogo de Sousa e após alguns contatos, no início de 2015 foi cedida amavelmente pela $\mathrm{Dr}^{\mathrm{a}}$ Isabel Silva, directora daquele museu, uma lista do espólio arqueológico que possuíam vindo do Museu de Etnologia do Porto, entre ele o pertencente ao MMP. Esta lista permite perceber que este espólio foi sendo depositado no Museu D. Diogo de Sousa nos anos de 1993, 1999, 2010 e 2011. Também permitiu verificar que algum do espólio do Museu de Etnologia foi incorporado noutros museus que consta da lista, nomeadamente no Museu Municipal da Póvoa de Varzim, fazendo crer que poderá incluir materiais do MMP.

Com estes novos dados, ainda que com algumas lacunas pois a lista apresenta números de inventário repetidos e outros que se pensam estar errados, foi possível não só localizar grande parte do espólio arqueológico do MMP, visto que até então apenas se conhecia o que estava em depósito no MNSR e o resgatado entre 2012-2013 das instalações do Museu de Etnologia, como também ter uma perceção do que ainda está por localizar.

\section{CONCLUSÃO}

Até ao momento desconhece-se o paradeiro de vários objectos da colecção arqueológica do Museu Municipal do Porto, não se sabendo se foram incorporados/depositados noutros museus além dos já conhecidos (MNSR e MDDS), ou se estão nas instalações do Quartel de S. Brás, para onde foi muito do espólio que estava no Museu de Etnologia do Porto. Pretende-se por isso com este artigo, não só dar conhecimento da existência deste importante acervo que se tem dispersado por circunstâncias adversas, mas também constituir uma chamada de atenção para as políticas patrimoniais e museológicas portuguesas que continuam a cair em erros recorrentes, contribuindo para que se perca no tempo e espaço coleções como esta.

Ainda que aparentemente estas coleções não sejam vistas como importantes, constituem elementos materiais que relatam e autenticam a história da museologia e arqueologia portuguesa. Neste caso concreto, fazem parte materiais arqueológicos recolhidos num período em a arqueologia portuguesa dava os seus primeiros passos e que se revelam importantes elementos para a compreensão da ocupação humana no nosso território ao longo dos tempos.

Prova disso são os vários estudos já desenvolvidos por diferentes investigadores que envolvem muitos dos objetos desta coleção arqueológica, cujos resultados foram materializados em publicações, catálogos, comunicações e exposições.

Por esse motivo torna-se necessária a divulgação deste espólio para que mais investigadores tenham conhecimento da sua existência e para que mais estudos sobre os mesmos venham a ser desenvolvidos. 


\section{BIBLIOGRAFIA}

ALARCÃO, Jorge de; ALCÃO, Adília Moutinho (1964) Vidros Romanos no Museu Soares dos Reis. Museu. Porto. Série 2. №8, pp.73-79.

ALMEIDA, António Manuel Passos (2008) - Museu Municipal do Porto: das origens à sua extinção. Porto. Dissertação de Mestrado em Museologia, apresentada à Faculdade de Letras da Universidade do Porto. Policopiado.

ALMEIDA, António Manuel Passos (2006-2007) - Contributos ao Estudo da Museologia Portuense no Século XIX. O Museu do Colecionador João Allen e o Museu Municipal do Porto, Revista da Faculdade de Letras Ciências e Técnicas do Património. Porto. I Série. vol. V-VI, pp. 31-55.

ARAÚJO, Luís Manuel de (1995) - A colecção Egípcia do Museu Nacional de Soares dos Reis. Museu. Porto. Círculo Dr. José de Figueiredo. IV série. nº 3, pp. 7-20.

BOTTAINI, Carlo E., GIARDINO, Claudio \& PATERNOSTER, Giovanni (2012) - Estudo de um conjunto de machados metálicos do norte de Portugal. Câmara Municipal de Oeiras. Estudos arqueológicos de Oeiras. 19, 2, pp. 19-34.

COUTO, Sónia Alexandra de Castro (2011) - Objectos da colecção arqueológica do Museu Nacional Soares dos Reis. Dissertação de Mestrado em História e Património apresentada à Faculdade de Letras da Universidade do Porto. Policopiado.

DINIS, Manuel Vieira (1976) - O Castro de S.Brás (Frazão) Paços de Ferreira. Guimarães. 86, Jan-Dez, pp. 217-222.

FORTES, José (1905-1908) - Thesouro de Viatodos. Da idade do Bronze. Portugalia. 2 (1-4), pp. 110-111.

FORTES, José (1899-1908) - A necrópole dolménica de Salles. Portugália s/n. Porto., pp. 666-686.

MACHADO, Ana Paula; MORAIS, Rui; ROCHA-PEREIRA, Maria Helena (2008) - Vasos gregos. Porto. IMC/MNSR.

MORAIS, Rui (2008-2009) - A colecção de lucernas do Museu Nacional de Soares dos Reis. Museu. IV série.17, pp. 65-79.

Museu Nacional Soares dos Reis (1952) - Catálogo-Guia do Museu Nacional Soares dos Reis: secção Lapidar. Porto. $2^{\underline{a}}$ edição.

PEIXOTO, Rocha (1902) - Guia do Museu Municipal do Porto. Porto. Typographia Central.

PEIXOTO, Rocha (1908) - Notícia acerca das explorações archeologicas da Cividade de Terroso e do Castro de Laúndos no concelho da Póvoa de Varzim (1906-1907 Portugália. Tomo II. 4, pp. 677-68o.

PESTANA, Maria Rosário Correia Pereira (2009) - O Museu de Etnografia e História do Douro Litoral: etnografia e museologia na construção do Douro Litoral, Trabalhos de Antropologia e Etnologia. 49, 1-4, pp. 79-92.
PORTELA, Maria Helena (1998) - Necrópoles Romanas do concelho de Amarante, Dissertação de Mestrado apresentada à Faculdade de Letras da Universidade do Porto.

ROCHA-PEREIRA, Maria Helena da, MORAIS, Rui e MACHADO, Ana Paula (2008) - Vasos Gregos. Colecção de João Allen. Porto: IMC.

SEVERO, Ricardo (1906) - Necrópoles lusitano-romanas de inumação: cemitério do Bairral. Portugália. Tomo II. Fasc. 3, pp. 417-430.

SANTOS, Joaquim Neves (1963) - Temas Regionais de Arqueologia e Etnografia II: Um Mosaico Romano de Lavra, Matosinhos, Edição do Autor.

SANTOS, Paula M. M. L. (2005) - Um coleccionador do Porto romântico: João Allen (1781-1848). Lisboa. Edição de autor com o apoio da FCT e IPM.

SOARES, Catarina (2016) - A Casa de S. João Novo e o Museu de Etnografia e História da Província do Douro-Litoral (1710-2016): estudo histórico-integrado, problemas e reflexões para a sua salvaguarda. Porto. Dissertação de Mestrado em História da Arte Portuguesa, apresentada à Faculdade de Letras da Universidade do Porto. Policopiado.

VITORINO, Pedro (1939) - Brandão o coveiro do Museu Municipal do Porto. Porto: Marânaus. 


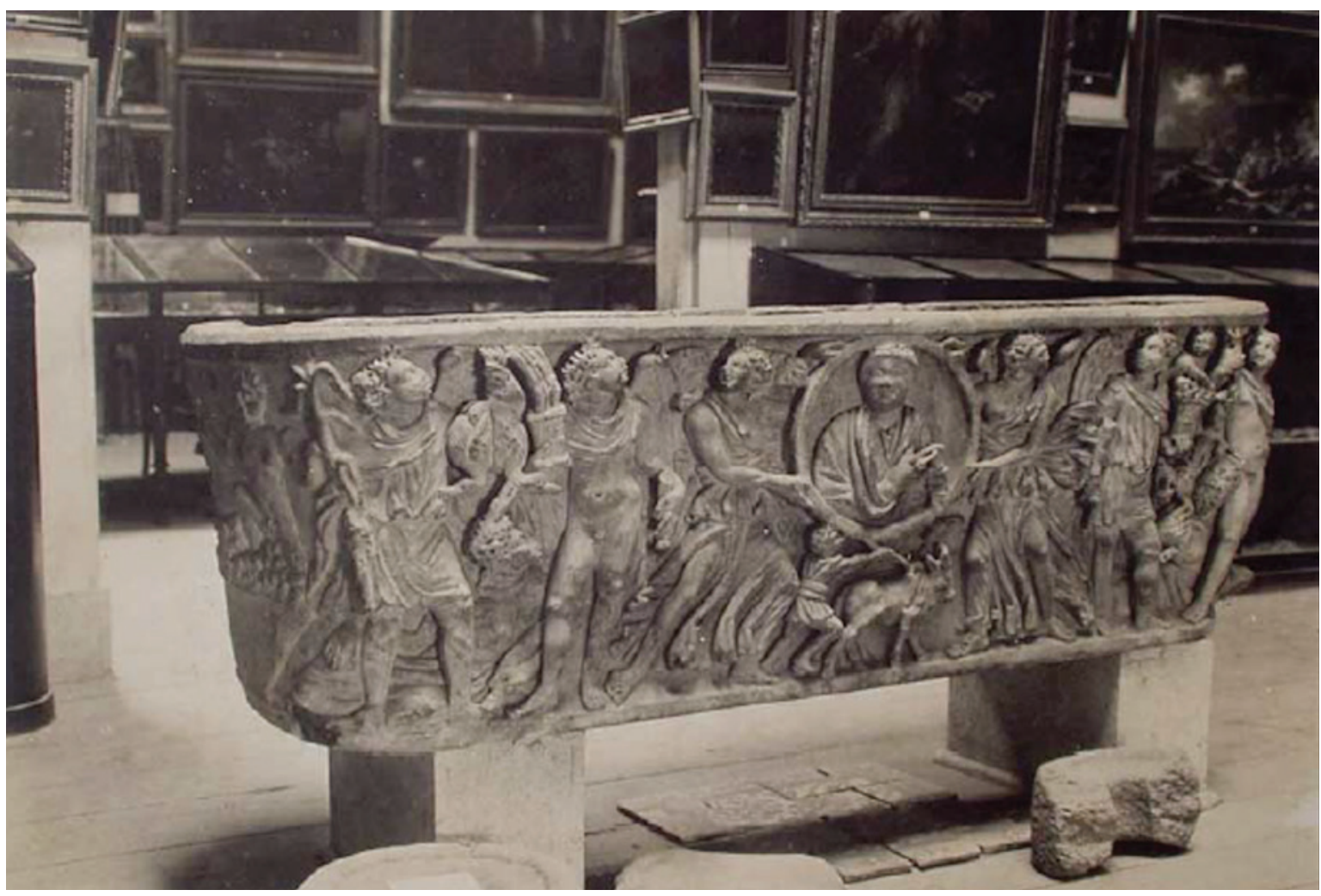

Figura 1 - Sarcófago romano, Museu Municipal do Porto, Rua da Restauração 1902 (fotografia retirada de Almeida, 2008, p.209).

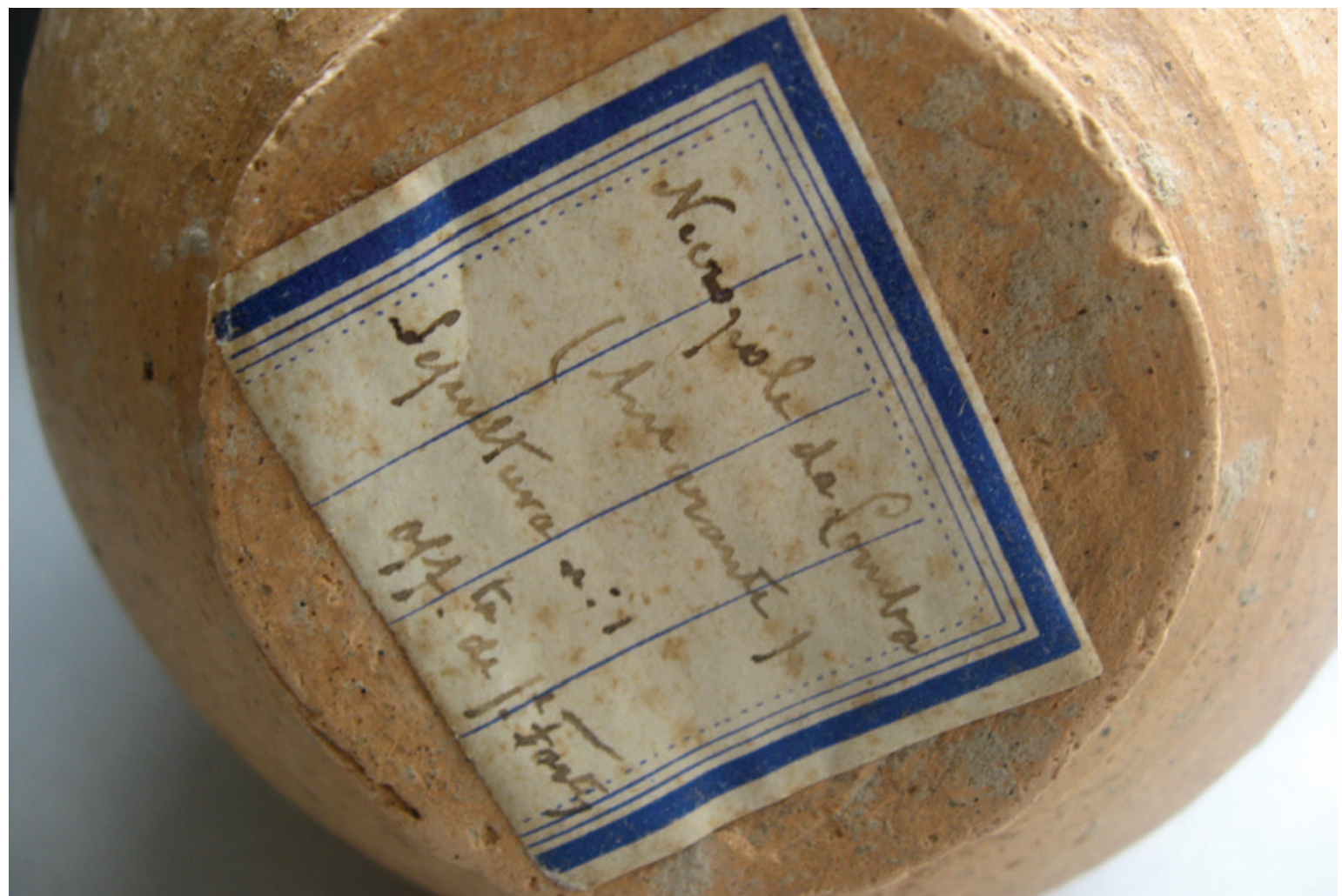

Figura 2 - Vasilha cerâmica proveniente da necrópole da Lomba, Amarante oferecida por José Fortes ao MMP (Fotografia de Ana Paula Machado, MNSR). 


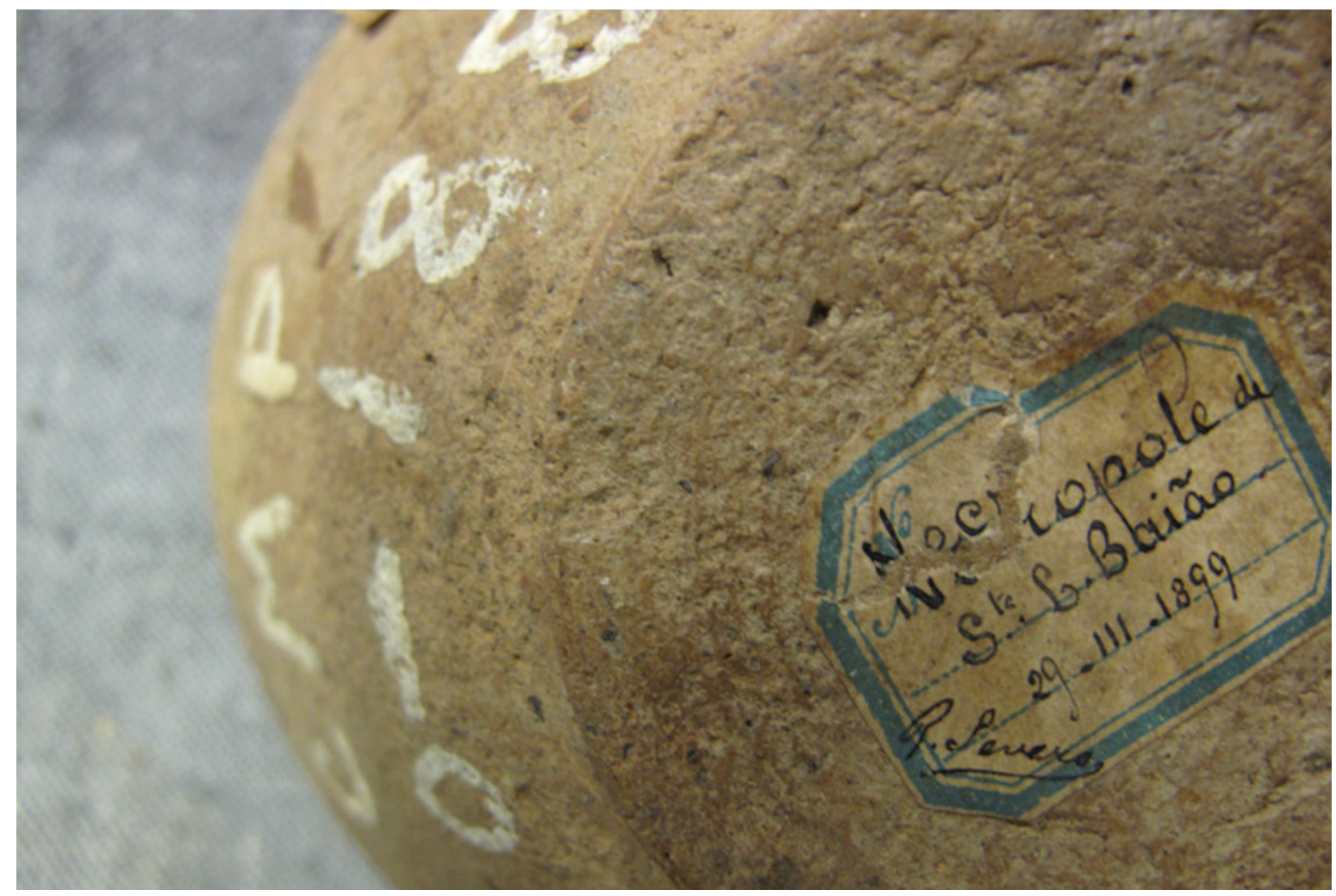

Figura 3 - Vasilha cerâmica proveniente da necrópole de Santa Leocádia, Baião, oferecida por Ricardo Severo ao MMP (Fotografia de Ana Paula Machado, MNSR)

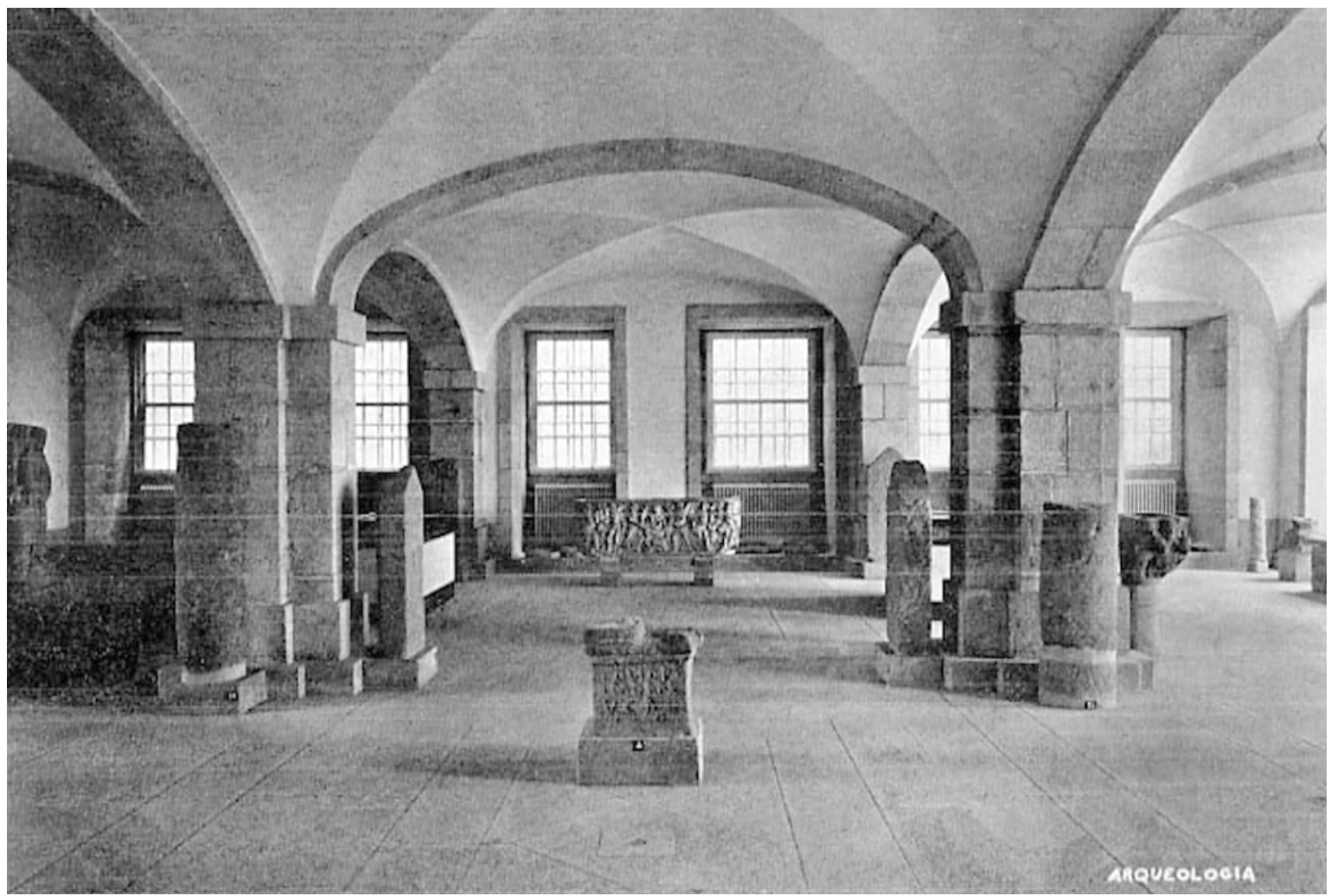

Figura 4 - Sala de Arqueologia do Museu Nacional Soares dos Reis (Fotografia cedida pelo Museu Nacional Soares dos Reis). 


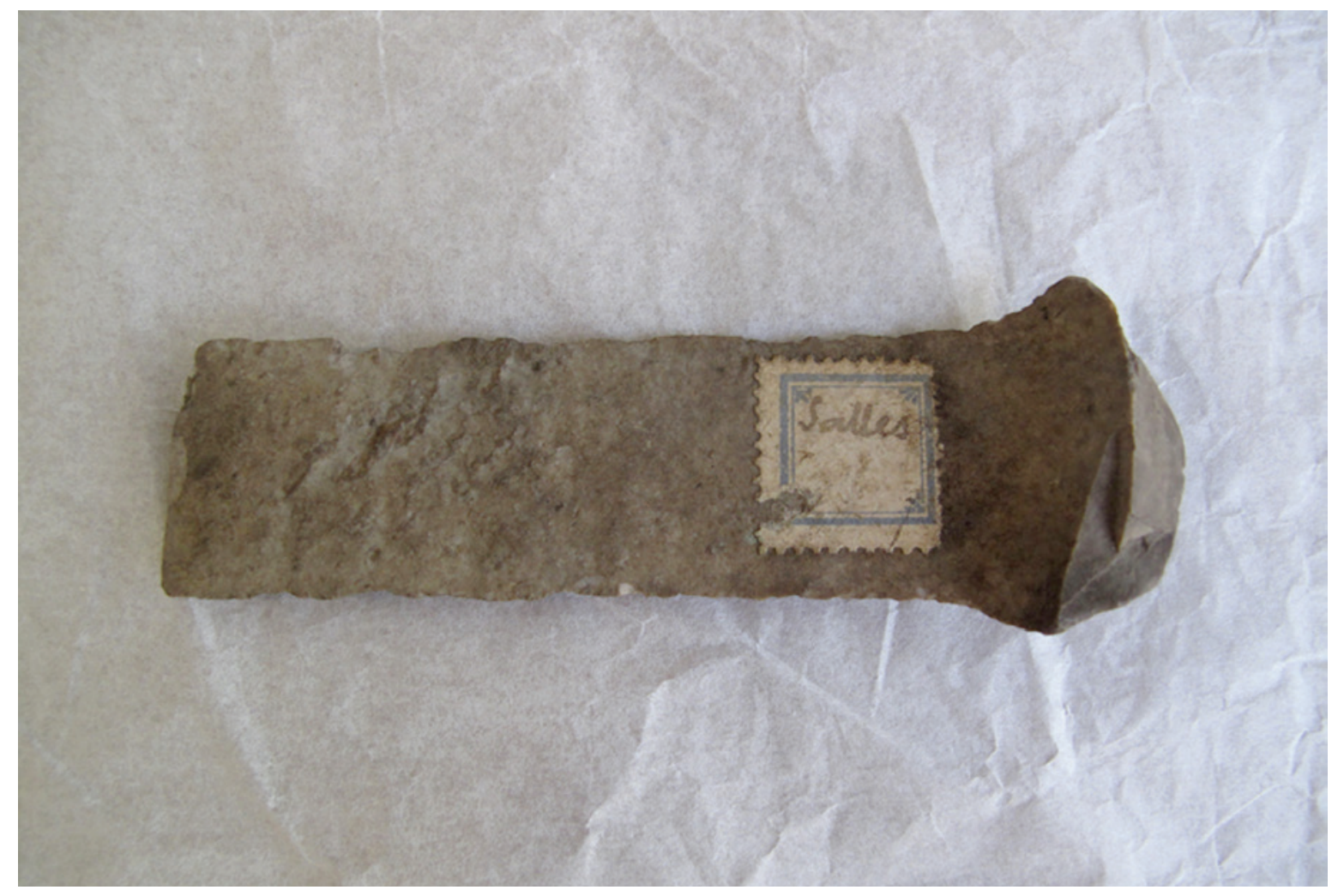

Figura 5 - Lâmina de Sílex proveniente da Necrópole de Sales, Montalegre (Fotografia de Sónia Couto).

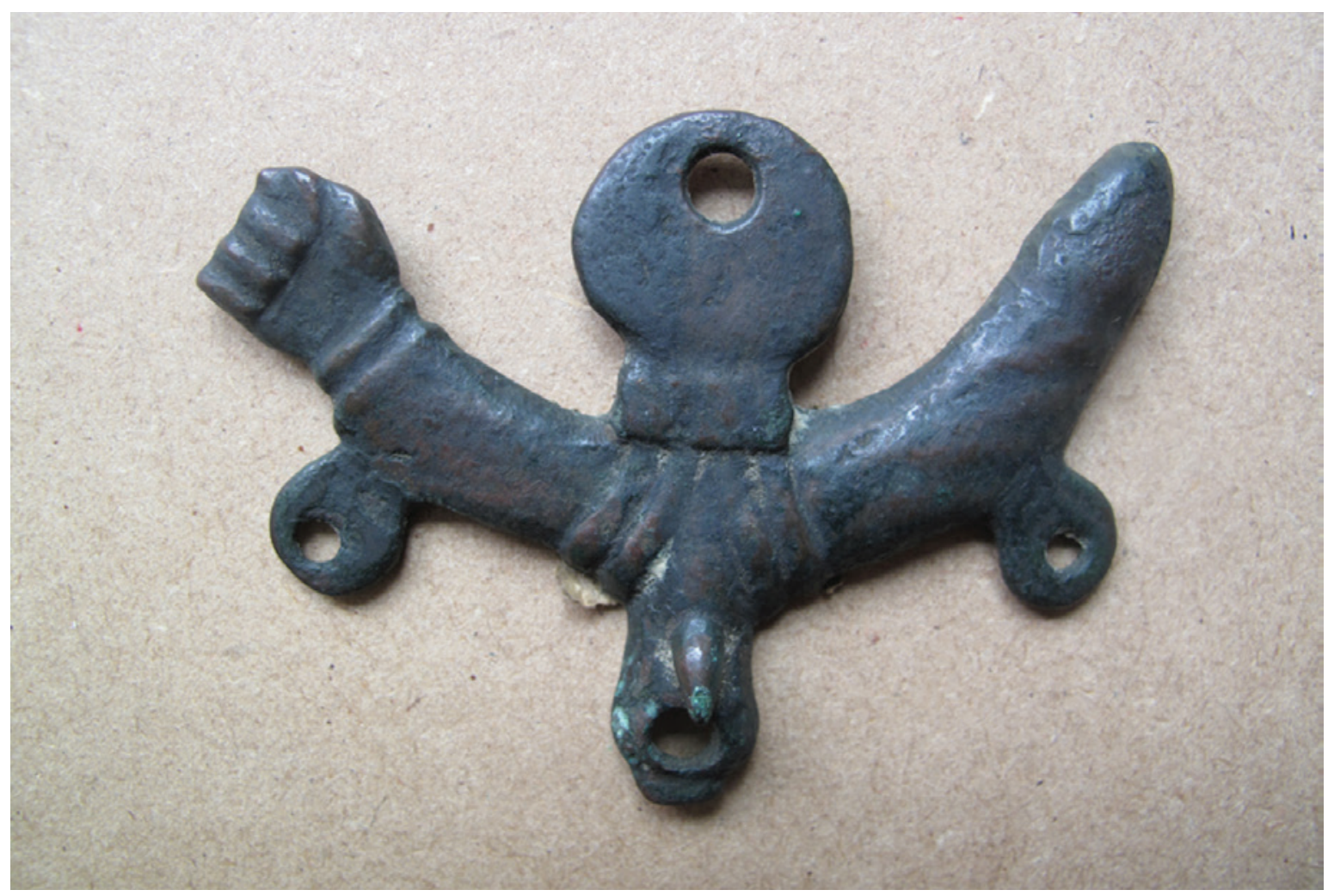

Figura 6 - Amuleto Figas Phallus proveniente de Pompeia (Fotografia de Sónia Couto). 


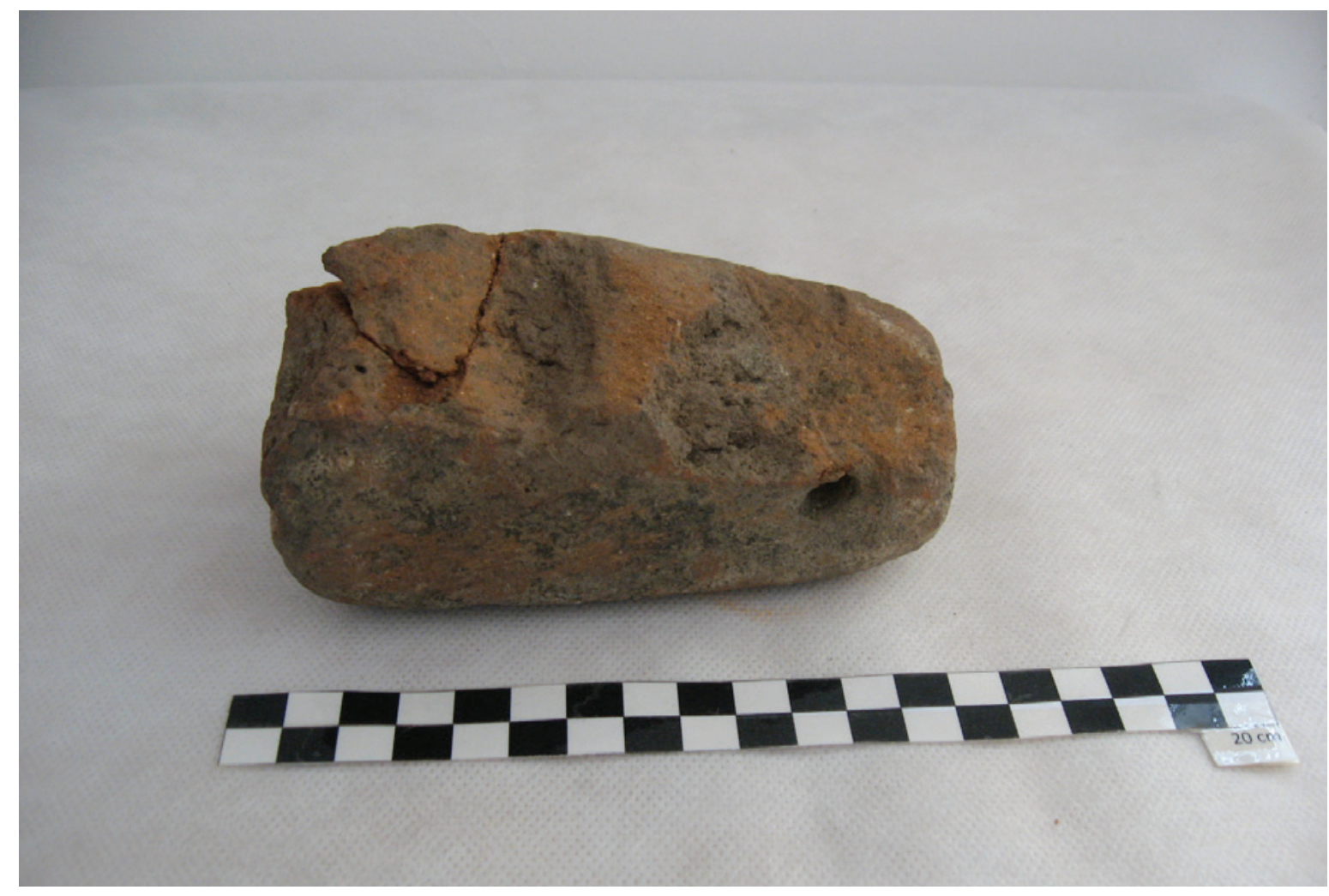

Figura 7 - Peso de tear proveniente do Castro de Ossela, Oliveira de Azeméis, (Fotografia de Sónia Couto).

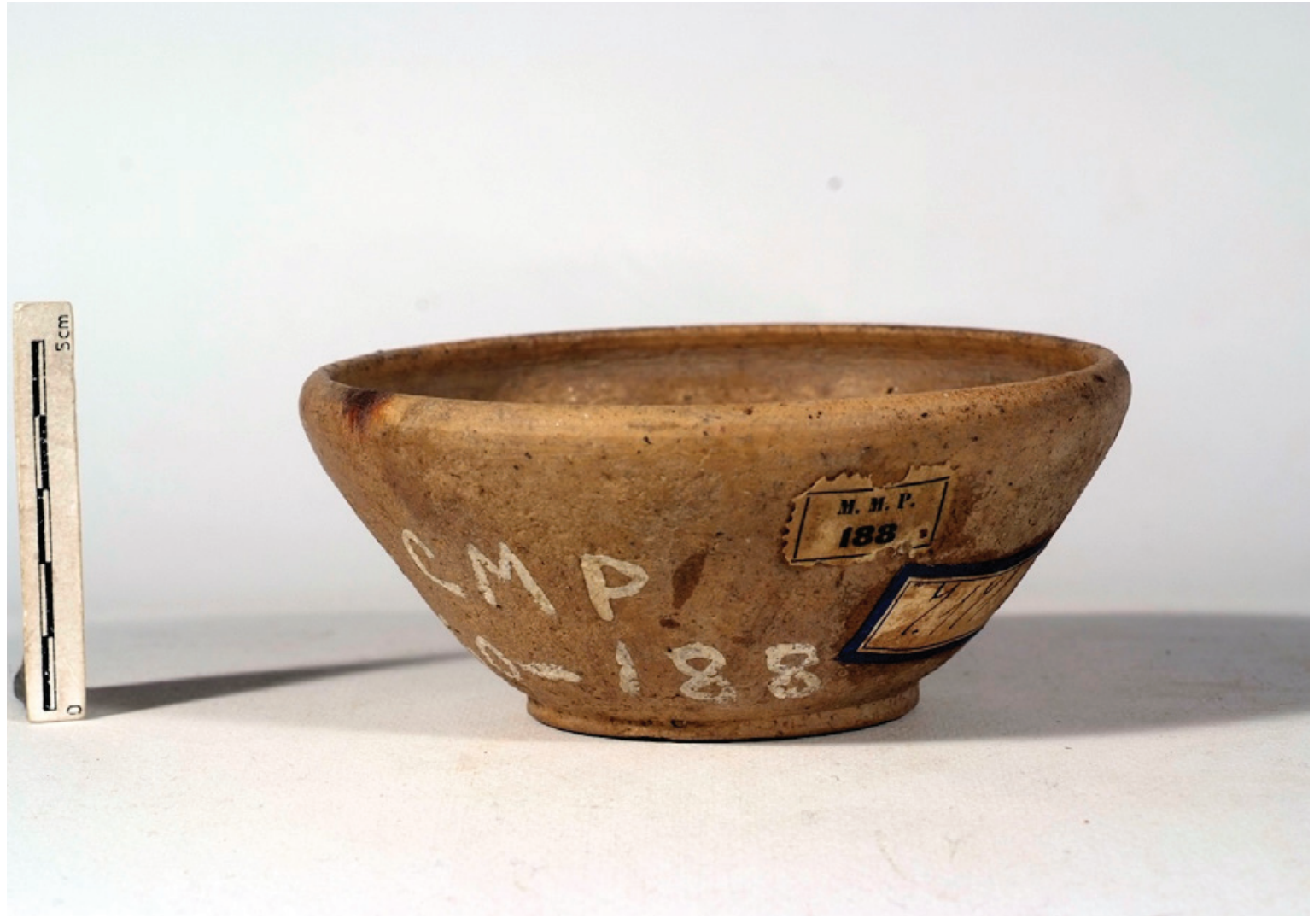

Figura 8 - Tigela em cerâmica proveniente da Necrópole do Bairral, Santa Leocádia, Baião (Fotografia de Ana Paula Machado, MNSR). 


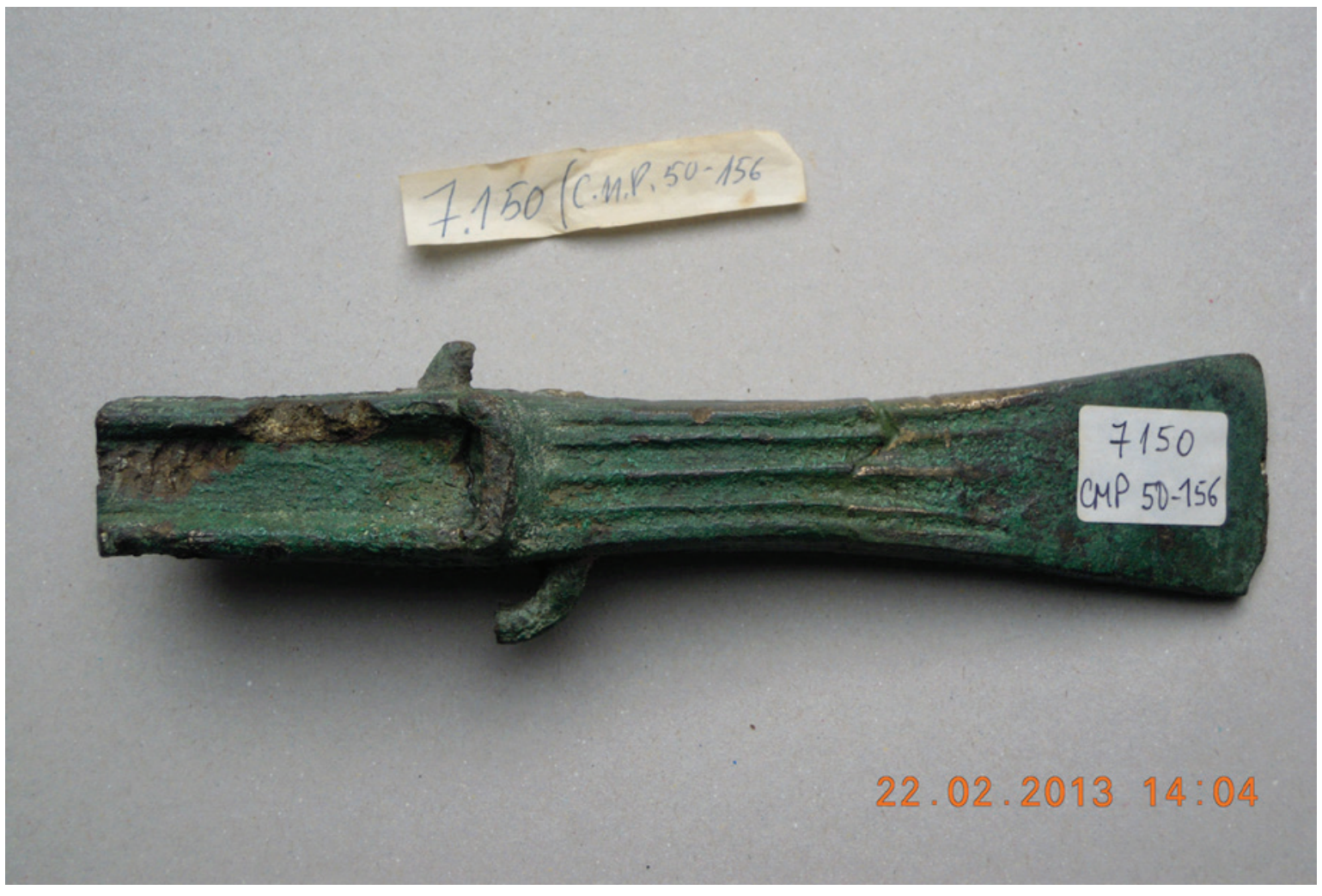

Figura 9- Machado de bronze proveniente de Viatodos, Famalicão (Fotografia de Ana Paula Machado, MNSR).

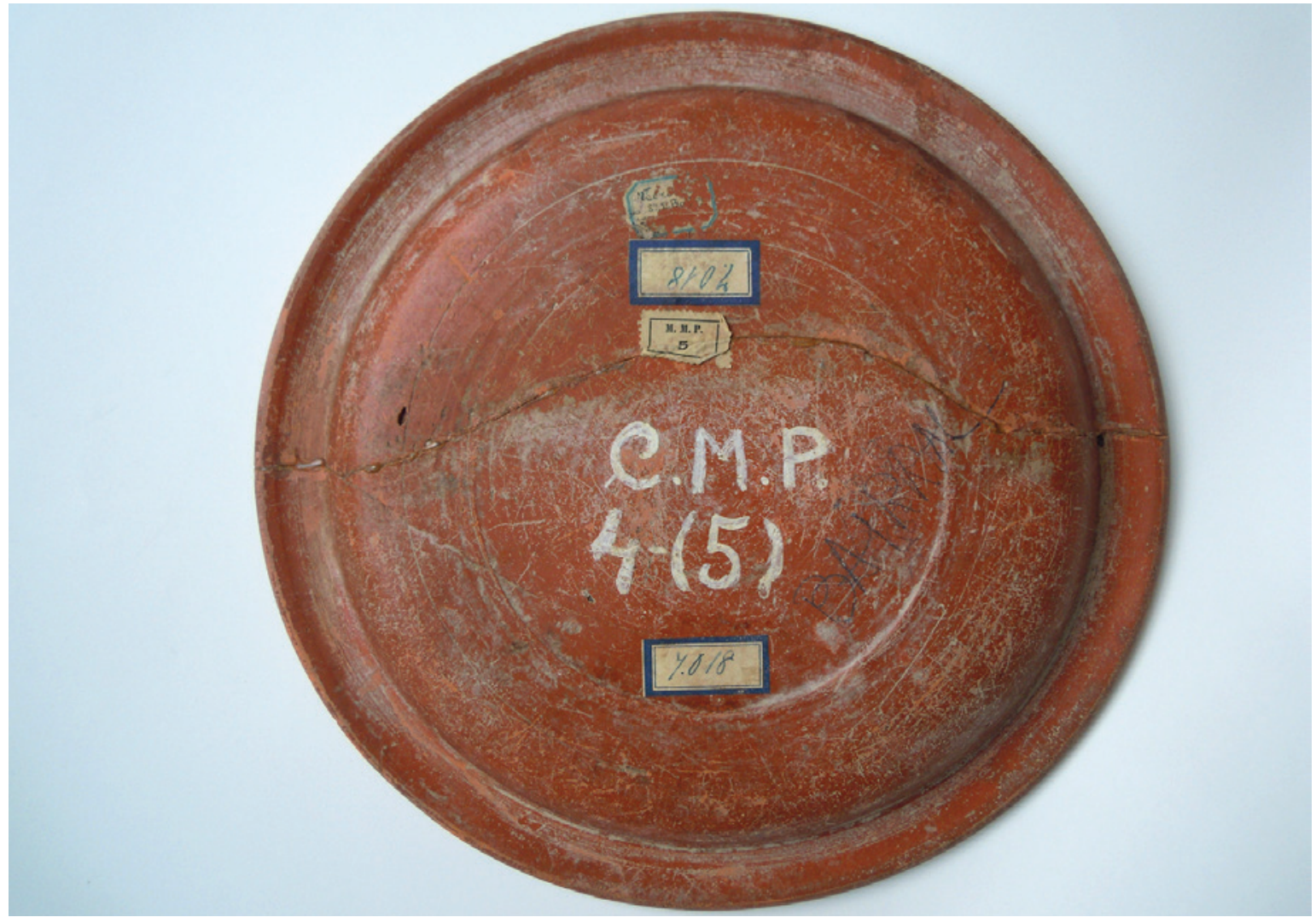

Figura 10 - Prato em sigillata proveniente da Necrópole do Bairral, Santa Leocádia, Baião (Fotografia de Ana Paula Machado, MNSR). 


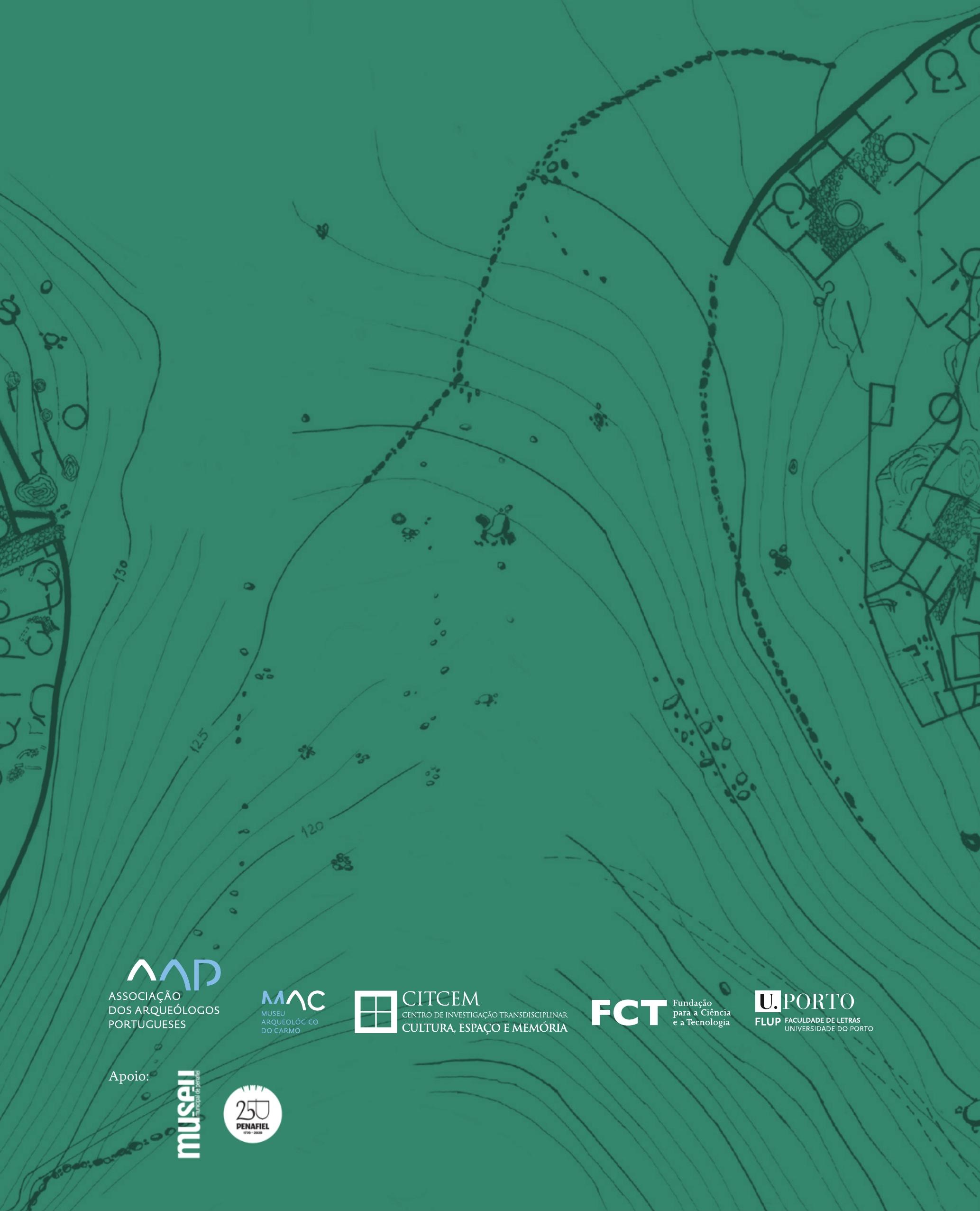

